\title{
Six new species of Barleria L. (Acanthaceae) from Northeast Tropical Africa
}

\author{
Ensermu Kelbessa ${ }^{1}$ \& lain Darbyshire ${ }^{2}$ (D)
}

Summary. Six new species of Barleria L. (Acanthaceae) are described from northeast tropical Africa: B. gidoleensis Ensermu \& I. Darbysh., B. baluganii Ensermu, B. ferox Ensermu \& I. Darbysh. and B. negeleensis Ensermu \& I. Darbysh. from Ethiopia and B. ensermui I. Darbysh. and B. shebelleensis Ensermu \& I. Darbysh. from Somalia. All the species are illustrated and their affinities and conservation status are discussed. A note on the presence of B. parviflora R. Br. ex T. Anderson in northern Somalia is also included. In addition, a foreword is presented on the great contribution to Acanthaceae taxonomy and African botany made by Professor Ensermu Kelbessa, who sadly passed away in August 2016.

Key Words. Flora, Horn of Africa, IUCN conservation assessment, rare species, taxonomy.

\section{Foreword: in memory of Professor Ensermu Kelbessa}

The paper published here has been several years in the planning, stemming from the treatment of the Acanthaceae for the Flora of Ethiopia \& Eritrea (Ensermu 2006) and from related studies on the genus Barleria in Northeast Tropical Africa. Ensermu and I had first agreed to publish these new species together during one of his many research visits to the Royal Botanic Gardens, Kew. He provided me with a draft manuscript and asked me to contribute extra information that I had acquired through my preparation for the Flora of Tropical East Africa account and wider studies of the genus, and to trace the illustrations that he had earlier commissioned at Kew. It is my deep regret that, whilst this task was always in my mind to complete, progress was slow due to other commitments and the manuscript was never quite finished. In August 2016, we received the tragic news that Ensermu had passed away suddenly, which was a great shock to all that knew him. On coming to terms with this untimely passing, I was resolved to complete the Barleria manuscript as a contribution to Ensermu's great legacy to African botany. In doing so I have taken the opportunity to name a species in his honour - Barleria ensermui I. Darbysh. - to commemorate his great contribution to botany and as a show of gratitude for his kind assistance when I was starting out as an Acanthaceae taxonomist and his continued help over the past decade. This is a species that Ensermu and I had previously discussed and agreed was new to science but which needed a full description and diagnosis.

A full and fitting obituary to Ensermu has been written by his great friend and colleague Prof. Sebsebe Demissew, with assistance from Dr Benny Bytebier and others (Sebsebe Demissew et al. 2016), and I will not repeat here all the information provided, except to say some words on his important contribution to Acanthaceae taxonomy.

Ensermu's interest in the Acanthaceae family was first ignited by Prof. Olov Hedberg of Uppsala University who introduced him to the remarkable variation in pollen morphology within the family. He conducted a palynological study of Asystasia Blume and related genera for his M.Sc. thesis at Addis Ababa University (Ensermu 1982). He later went on to study towards a Ph.D. under the supervision of Dr Mats Thulin at Uppsala University with the support of a scholarship from the Ethiopian Flora Project, a wonderful collaboration between the Department of Systematic Botany at Uppsala and the National Herbarium at Addis Ababa University. Through these studies, he produced a detailed taxonomic revision of Justicia L. sect. Ansellia C. B. Clarke (Ensermu 1990), a complex group of 12 species from Africa and southern Arabia, publishing two new species in the process (Ensermu 1989a). This excellent work is the authoritative account on this challenging group.

\footnotetext{
Accepted for publication 7 November 2017. Published online 23 December 2017

1 The National Herbarium, Department of Plant Biology \& Biodiversity Management, Faculty of Science, Addis Ababa University, P.O. Box 3434, Addis Ababa, Ethiopia.

2 Herbarium, Royal Botanic Gardens, Kew, Richmond, Surrey, TW9 3AB, UK. e-mail: i.darbyshire@kew.org
} 
Ensermu was to continue to return to the genus Asystasia throughout his career, publishing or copublishing eight new species and refining the generic delimitation (Ensermu 1989b, 1993, 1998; Ensermu et al. 1992; Vollesen \& Ensermu 2010) and revising the horticulturally and ecologically important Asystasia gangetica (L.) T. Anderson complex (Ensermu 1994) amongst other achievements. Undoubtedly his greatest taxonomic achievement, however, was the writing of the treatment of the Acanthaceae family for the Flora of Ethiopia and Eritrea (Ensermu 2006). This major undertaking covers 40 genera and 205 species, many of which were poorly known prior to this excellent account. This work, and the draft manuscripts that Ensermu kindly shared with Dr Kaj Vollesen and myself, were of great assistance in the writing of the treatment of Acanthaceae for Flora of Tropical East Africa, and indeed Ensermu was a coauthor on the second of that two-part account (Darbyshire et al. 2010). In total, Ensermu published 21 new species to science and added a further three new name combinations, all in the Acanthaceae family.

Ensermu was a skilled, careful and thorough taxonomist, with a passion for seeing the plants that he studied in their natural environment through extensive fieldwork as well as in herbaria. He produced work of a consistently high quality that will long be used as key references in our understanding of Acanthaceae systematics. He was also a passionate advocate of plant conservation and the protection of rare and threatened species, with a great love for and knowledge of the Ethiopian flora (see for example Vivero et al. 2005, 2006). He was an excellent mentor to his many students and a close friend and colleague to the many plant taxonomists, ethnobotanists, ecologists and conservationists who shared his passion for African plants. We have lost a true champion of African botany.

Prof. Ensermu Kelbessa was warmly remembered through a memorial lecture event held at Addis Ababa University on $20^{\text {th }}$ February 2017, attended by many of his friends, colleagues and family members, at which I had the honour of presenting on his contribution to African plant taxonomy and conservation.

Iain Darbyshire, Royal Botanic Gardens, Kew.

\section{Introduction}

Barleria L. is one of the largest genera of Acanthaceae, comprising approximately 300 species (Ensermu 2006; Darbyshire 2010). It is particularly diverse in the dry woodlands and bushlands of eastern, northeastern and southern tropical Africa (Balkwill \& Balkwill 1998), and many of the species have highly restricted ranges and are of high conservation concern (Darbyshire \& Luke 2016).
In volume five of the Flora of Ethiopia and Eritrea (Hedberg et al. 2006 - FEE), 39 species of Barleria were treated, including 11 that were considered to be potentially new species to science but, due to time pressures to complete the Flora volume, were not formally named and published (Ensermu 2006). During the preparation of the FEE manuscript, several as then un-named species were also observed in herbarium material from neighbouring Somalia and provisional descriptions were made by the first author of the current paper. Some of these Somali taxa were subsequently delimited in full during preparation of the Flora of Somalia account of Barleria, where Hedrén documented 25 species (Hedrén 2006a), four of which were treated as new species - B. albomarginata Hedrén, $B$. dentata Hedrén, B. glaucobracteata Hedrén and B. ilicifolia Hedrén - and one of which was raised from varietal to species rank - B. linearifolia Rendle var. brevispina Fiori $=$ B. brevispina (Fiori) Hedrén. The new names published in that volume were briefly nomina nuda but later in the same year, Hedrén (2006b) formally validated them. Barleria glaucobracteata has subsequently been synonymised within B. quadrispina Lindau (Darbyshire 2010). Several other apparently distinct species of Barleria from Somalia were listed only as Notes under the related species treated by Hedrén (2006a) and remain undescribed. Some of these, those that have been recorded close to the Ethiopian border and so may be found within Ethiopia in the future, were included in the key to species of Barleria in FEE (Ensermu 2006: 402 - 404).

In this paper, six species of Barleria are formally described from Northeast Tropical Africa. Four of these are from amongst the 11 species treated as Barleria spp. in FEE and two are species from Somalia that were noted as potentially distinct in the Flora of Somalia treatment and included in the key to species in FEE.

Of the seven other "Barleria spp." of FEE, "B. sp. (= Gereau 1320)" [sp. 3 of FEE] is probably one of the many forms of B. ventricosa Nees (I. Darbyshire, pers. obs.); "B. sp. (= Burger 3373)" [sp. 26 of FEE] is now known to be $B$. brevispina (Hedrén 2006a), but with white-flowered plants from the Sidamo region considered to be a form of $B$. polhillii I. Darbysh., and "B. sp. (= Mooney 5618)" [sp. 30 of FEE] has been matched with B. marginata Oliv. (Darbyshire 2010). The remaining four are still considered to be probable new species to science but there is insufficient material of each for formal description at this stage. This is similarly the case for a number of potentially new species from Somalia where further collecting efforts targeting Barleria are very likely to yield further new discoveries.

During preparation of this paper, a small error was detected in the key to Barleria for the Flora of Ethiopia $\mathcal{E}$ Eritrea for which the number of seeds was mixed up in couplet 2; it is corrected below: 
2 Capsule 4-seeded, not prominently beaked..............11 Capsule 2-seeded (except in B. grandis where 4-seeded), prominently beaked. .26

\section{Species accounts}

The descriptions of the new species are based primarily on the study of herbarium material held at the ETH and K herbaria. All specimens and duplicates cited have been seen by at least one of the two authors. The provisional conservation assessments follow the Categories and Criteria of IUCN (2012). Only Extent of Occurrence (EOO) is used as a measure of species range size as information on the new species is considered to be too limited to calculate Area of Occupancy (AOO) with any accuracy, except in the case of Barleria baluganii where AOO can be used with more confidence.

Barleria gidoleensis Ensermu $\mathcal{E}$ I. Darbysh. sp. nov. Type: Ethiopia, Gamo Gofa Region: 49 km SW of Arba Minch on hillside leading to Gidole, c. $5 \mathrm{~km} \mathrm{~N}$ of Gidole, fl. \& fr. 22 Nov. 1973, Ash 2264 (holotype ETH; isotype $\mathrm{K}$ ).

http://www.ipni.org/urn:lsid:ipni.org:names:77167050-1

Barleria sp. (= Ensermu K. Eं Zerihun W. 612) sensu Ensermu (2006: 409), pro maj. parte.

Spiny shrub $1-1.8 \mathrm{~m}$ high and to $1.8 \mathrm{~m}$ wide; stems soon turning woody, much-branched, pilose with longstalked glandular hairs, and with up to $2 \mathrm{~mm}$ long bristly hairs; internodes very short, up to $10-20 \mathrm{~mm}$ long. Leaves subsessile, blade ovate to sub-orbicular, up to $15-18 \times 11-17 \mathrm{~mm}$, base cordate or rounded, margins entire, apex mucronate, pilose beneath with long-stalked glandular hairs and bristly hairs, nearly glabrous above; lateral veins $3-4$ pairs, raised beneath, nearly indistinct above. Axillary spines with stalk nearly lacking or to $6 \mathrm{~mm}$ long, 2-branched; branches widely divergent, \pm straight $14-24$ mm long, grey, glandular-pubescent except the spinose apex which is glabrous. Flowers axillary, solitary, stalked, bracteoles terminating $2-4 \mathrm{~mm}$ long common stalk (peduncle), the 2 bracteoles each $18-25 \times 1 \mathrm{~mm}$, spiny, pubescent with glandular hairs and bristly hairs; pedicel 2-4 mm long, pubescent with glandular and bristly hairs. Calyx with anterior and posterior lobes sub-equal, narrowly oblong, $13-15 \times 3-4 \mathrm{~mm}$, apex mucronate, external surfaces pubescent with glandular hairs and ascending bristly hairs; lateral lobes linear-subulate, $10.5-14.5 \times 2 \mathrm{~mm}$, apex mucronate, indumentum as outer lobes. Corolla light blue-violet or pale blue (black in dry state), (42 -) 49 - $54 \mathrm{~mm}$ long; tube $34-36 \mathrm{~mm}$ long, $\pm 5 \mathrm{~mm}$ broad at base, $\pm 10 \mathrm{~mm}$ at mouth, pubescent externally and at base of filaments internally; limb 5-lobed in weak " $2+3$ " configuration, lobes sub-equal, $18-20 \times 8-10 \mathrm{~mm}$, oblong-elliptic, \pm rounded at apex, pubescent externally, adaxial pair of lobes separated from tube $2 \mathrm{~mm}$ below the other 3 lobes and slightly smaller, $\pm 3 \mathrm{~mm}$ broad at base, the other 3 lobes $\pm 4 \mathrm{~mm}$ broad at base. Stamens inserted $\pm 16 \mathrm{~mm}$ above base of corolla tube, exserted from corolla tube for $\pm 13 \mathrm{~mm}$ of their length; filaments 23 - $31 \mathrm{~mm}$ long, pilose at base; anthers $\pm 6 \mathrm{~mm}$ long; staminodes 3 , filaments 5 $6 \mathrm{~mm}$ long, antherodes absent. Ovary $\pm 4 \mathrm{~mm}$ long, black, surrounded by disc in proximal half, glabrous; style $\pm 50 \mathrm{~mm}$ long, glabrous; stigma sub-capitate. Capsule $22-26 \times 7 \mathrm{~mm}$, black to dark brown, shining, glabrous, 4-seeded; seeds $\pm 7 \times 6 \mathrm{~mm}$, triangular-ovate in face view, with golden-yellow hygroscopic hairs. Fig. 1.

RECOGNITION. Barleria gidoleensis is morphologically closest to $B$. longissima Lindau and is very similar vegetatively, but it differs in having a much smaller corolla (42 -) 49 - $54 \mathrm{~mm}$ long (vs 110 - $126 \mathrm{~mm}$ long) with the tube narrow in its lower portion and gradually enlarged towards the mouth and its lobes separated at different levels (vs corolla with very long and uniformly cylindrical tube and the lobes separated at the same level in B. longissima); a much shorter style, $\pm 50 \mathrm{~mm}$ long (vs 120 - $130 \mathrm{~mm}$ long in B. longissima); and smaller calyx with the outer lobes $13-15 \mathrm{~mm}$ long (vs 19 - 22 mm long).

DISTRIBUTION. Barleria gidoleensis is restricted to Gamo Gofa and Sidamo Floristic Regions in southern Ethiopia. Map 1, green triangles.

SPECIMENS STUDIED. ETHIOPIA. Gamo Gofa Region: $49 \mathrm{~km} \mathrm{SW}$ of Arba Minch on hillside leading to Gidole, c. $5 \mathrm{~km} \mathrm{~N}$ of Gidole, 1400 m, 22 Nov. 1973, Ash 2264 (ETH holotype, K isotype); eastern slopes of Gughe highlands above Arba Minch, c. $6^{\circ} 03^{\prime} \mathrm{N}$, 37³5'E, 1700 - 2000 m, 3 Sept. 1975, Gilbert, Thulin $\mathcal{E}^{\circ}$ Getachew T. 517 (ETH, K, UPS); $4 \mathrm{~km} \mathrm{~N}$ of Gidole, 24 Dec. 1983, Ensermu K. E Zerihun W. 612 (ETH). Sidamo Region: Amaro Mts, Ridge, c. 5 $39^{\prime} \mathrm{N}, 38^{\circ} 06^{\prime} \mathrm{E}$, $5800 \mathrm{ft}$ [1770 m], 14 Dec. 1952, Gillett 14753 (K).

HABITAT \& ECOLOGY. Barleria gidoleensis occurs in bushland and scrub of Dodonaea viscosa (L.) Jacq. var. angustifolia (L. f.) Benth. and in Acacia-Combretum open woodland transitioning to Juniperus procera Hochst. ex Endl. forest. At one site it was recorded from an assemblage of Dodonaea with Pterocephalus frutescens Hochst. ex A. Rich., Ipomoea kituiensis Vatke, Echinops macrochaetus Fresen., Acanthus sennii Chiov. and Piliostigma thonningii (Schumach.) Milne-Redh. It grows at $1400-2000 \mathrm{~m}$ elevation.

CONSERVATION STATUS. This species is currently known from three localities and has an EOO of c. $1450 \mathrm{~km}^{2}$, which falls within the Endangered range threshold for IUCN Criterion B1. None of its known localities are 

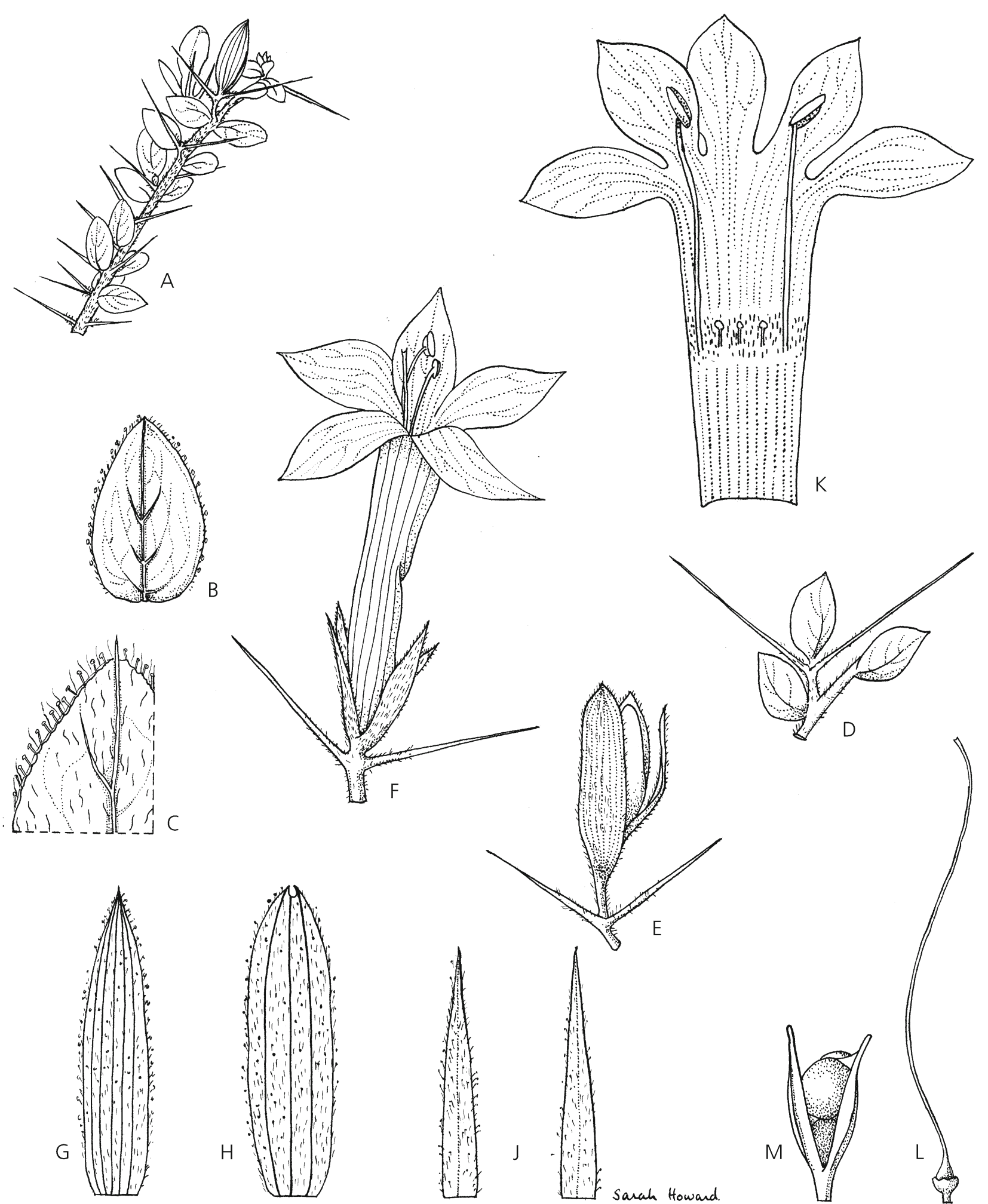

Fig. 1. Barleria gidoleensis. A flowering branch $\times 1$; B leaf blade, abaxial surface $\times 2$; C leaf blade, apical portion $\times 30$; D detail of spines $\times 1.5$; E flower bud with subtending bracteoles $\times 2$; F open flower $\times 1.5$; G posterior calyx lobe $\times 4$; $\mathrm{H}$ anterior calyx lobe $\times$ 4 ; J lateral calyx lobes $\times 4 ; \mathrm{K}$ dissected corolla with androecium $\times 1.5 ; \mathrm{L}$ gynoecium with disc $\times 1.5 ; \mathrm{M}$ capsule with seeds, dehisced $\times$ 1.2. A - D \& L from Ash 2264; E - K \& M from Ensermu K. \& Zerihun W. 612. DRAWN BY SARAH HOWARD.

within Protected Areas, although the Nechisar National Park falls partly within its EOO. Google
Earth imagery indicates that there has been extensive conversion to agricultural land in the Gidole area, 


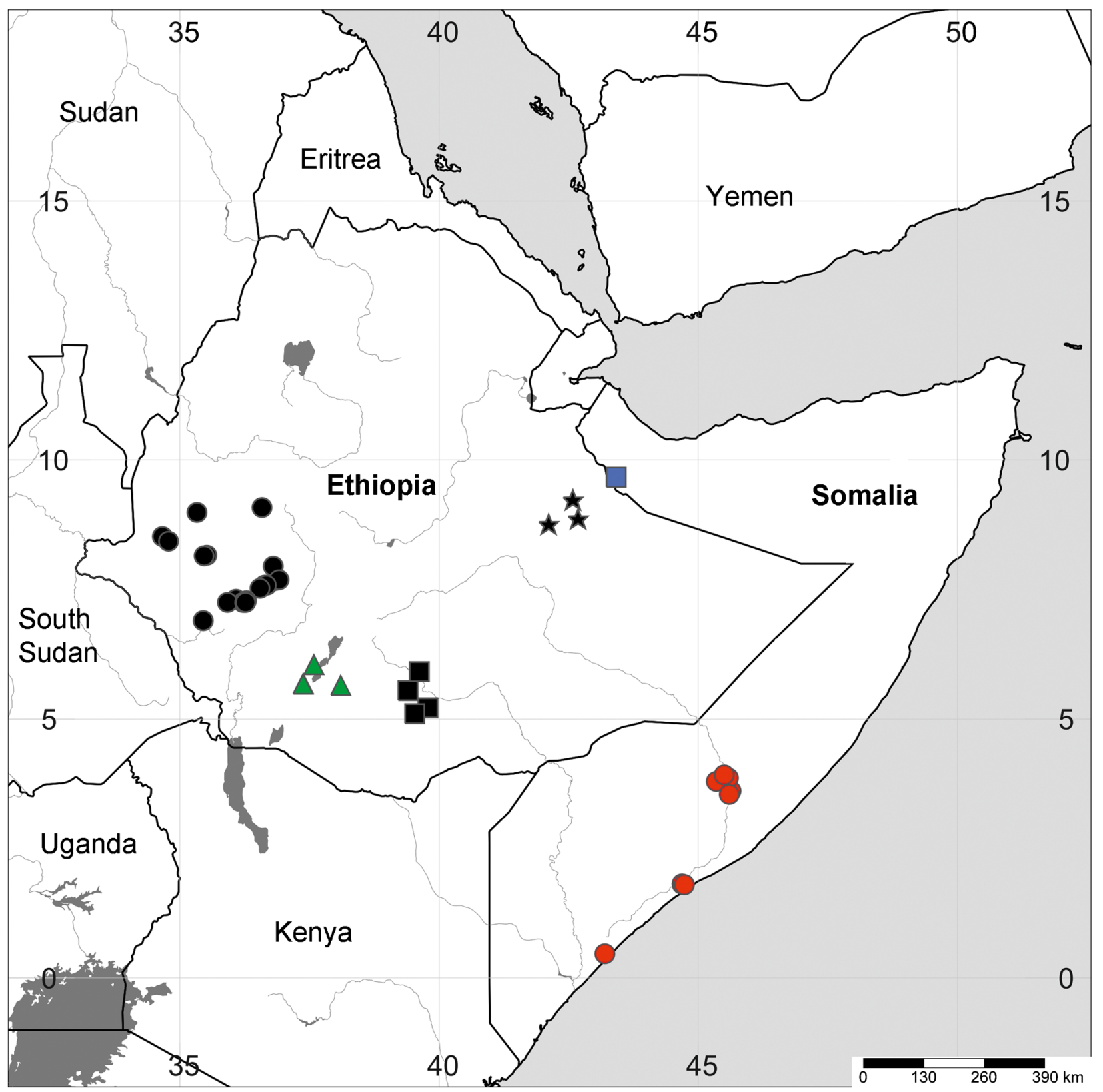

Map 1. Distribution of new species of Barleria in Ethiopia and Somalia: $B$. gidoleensis (green triangles); $B$. ensermui (blue square); B. baluganii (black circles); B. ferox (black stars); B. negeleensis (black squares); B. shebelleensis (red circles).

whilst the SE slopes of the Gughe highlands are being impacted by the rapid expansion of Arba Minch town and associated villages. Whilst this species may be able to tolerate some disturbance, as it appears to grow in secondary assemblages such as Dodonaea scrub, it will be adversely impacted by habitat clearance for settlement and agriculture. With known threats to two of its three locations (the Sidamo location is too vague to consider likely threats), this species is considered to be Endangered EN B1ab(iii).

ETYMOLOGY. Barleria gidoleensis is named after the small town (and administrative unit) of Gidole, which is near to the type locality for this species.
NOTES. The four-seeded capsule, fusiform in face view and lacking a prominent beak, places this species in sect. Barleria (Balkwill \& Balkwill 1997; Darbyshire 2009). Based on their morphological similarity, it is clearly closely allied to B. longissima Lindau, a rare Ethiopian endemic species that also occurs in Gamo Gofa and Sidamo Floristic Regions. However, they are easily separated by the characters listed in the Recognition section, in particular the much shorter and less strictly cylindrical corolla tube of B. gidoleensis. Similar species pairs are found elsewhere in Barleria sect. Barleria, for example B. gracilispina (Fiori) I. Darbysh. and B. paolioides I. 
Darbysh. from east and northeast Africa, the former having a long, strictly cylindrical corolla tube and subregular limb and broad outer calyx lobes, the latter having a short and narrowly funnel-shaped corolla tube and a more zygomorphic limb, and narrow outer calyx lobes (Darbyshire 2010). In this latter case, there is an intermediate species from Somalia that may be of hybrid origin, B. paolii Fiori.

In the FEE treatment, Barleria gidoleensis was considered to be conspecific with specimens from northern Kenya including Verdcourt E D Dale 2216 (K) (Ensermu 2006). However, the Kenyan plants were later named B. ramulosa C. B. Clarke var. dispersa I. Darbysh. and several key differences were noted to B. gidoleensis (Darbyshire 2010). These include shorter axillary spines and bracteoles (7 - $20 \mathrm{~mm}$ long), shorter lateral calyx lobes $(5-9.5 \mathrm{~mm}$ long), smaller corollas (21 - $41 \mathrm{~mm}$ long) with a considerably narrower tube and less oblong lobes, shorter staminal filaments (11 - $18 \mathrm{~mm}$ long), and smaller capsules (11 - $20 \mathrm{~mm}$ long) in B. ramulosa.

Barleria gidoleensis is also strikingly similar to B. molensis Wild, a species restricted to the serpentine of the Great Dyke in Zimbabwe (see Darbyshire 2015: 59). They share a similar habit, indumentum and corolla morphology, although plants of $B$. gidoleensis appear to be larger and usually have a shorter corolla tube. They are most easily separated by the differing leaf shape, B. molensis having elliptic or obovate leaves with a cuneate or attenuate base, by the larger calyces in B. molensis (posterior lobe $20-26 \times 4-9 \mathrm{~mm}$ ), and by the differing flower colour, those of $B$. molensis being white, although they can fade to pale bluish (pale blue to blue-violet in B. gidoleensis). It would be interesting to carry out molecular analyses to see if these geographically and ecologically disjunct species are closely related.

The duplicate at K of the specimen Gilbert et al. 517 differs from other material seen (and even from the duplicate of this specimen at UPS) in bearing smaller axillary spines and less glandular hairs; there is no mature flower on the K sheet, but the UPS sheet has a mature flower that is a good match for Barleria gidoleensis. The $\mathrm{K}$ sheet is probably just from an immature plant.

Barleria ensermui I. Darbysh. sp. nov. Type: Somalia, plain on Buramo - Hargeisa road, 28 miles E of Buramo, fl. \& fr. 13 Feb. 1933, Gillett 4999 (holotype K 000963594; isotype K 000963593).

http://www.ipni.org/urn:lsid:ipni.org:names:77167078-1

Barleria mucronifolia sensu Hedrén (2006a: 429), pro parte quoad Gillett 4999, non Lindau.

Barleria sp. (= Gillett 4999) sensu Ensermu (2006: 403).
Dwarf, harshly spiny shrublet, much branched with short internodes and contracted lateral branches, stems somewhat quadrangular, white-puberulous, the hairs retrorse. Axillary spines paired, of sterile, reduced bracteoles, $7-18 \times 1-3.5 \mathrm{~mm}$, curved, with few spines along margins. Leaves on short petiole to $1.5 \mathrm{~mm}$ long or subsessile; blade elliptic or somewhat oblanceolate, $9-14 \times 4-6 \mathrm{~mm}$, base cuneateattenuate, margin entire, apex acute and mucronate for up to $1 \mathrm{~mm}$, surfaces white-puberulous, the hairs curled, and with longer pale yellow-buff ascending or appressed hairs; lateral veins $3-5$ pairs, these and midrib pale and \pm prominent beneath. Inflorescences axillary and sub-terminal, 2 - 6-flowered (sub)sessile contracted unilateral cymes up to $2.5 \mathrm{~cm}$ long at maturity; bracts foliaceous; bracteoles at first purplebrown, later turning pale-scarious, pairs unequal, larger of each pair held adjacent to calyx, lanceolate, $18-27 \times 4.5-9 \mathrm{~mm}$, base abruptly widened and rounded, margin with $2-4$ lateral spines per side up to $2.5-4.5 \mathrm{~mm}$ long, apex attenuate into a long spine, this often somewhat curved; smaller bracteole of each pair held adjacent to inflorescence axis, shorter and narrower than the larger one; pair of bracteoles at base of inflorescence usually narrower, the larger 3.5 $4.5 \mathrm{~mm}$ wide, and with a more cuneate-attenuate base; flowers sessile. Calyx in dry state at first purple-brown with darker palmate-reticulate venation, later turning pale-scarious; anterior lobe (oblong-) elliptic or obovate, $11.5-15 \times 4.5-8 \mathrm{~mm}$, base cuneate or attenuate, margin with small spinulose bristle-tipped teeth in distal half, apex with one or often two short spines to $1 \mathrm{~mm}$ long, external surface with long palebuff ascending hairs and few to numerous short white curled hairs, also with scattered short-stalked cupshaped orange glands and few minute glandular hairs; posterior lobe as anterior lobe but up to $17 \times 11.5 \mathrm{~mm}$ excluding long apical spine $3.7-9 \mathrm{~mm}$ long, margin with 2 or 3 conspicuous spines to $1.5-4.5 \mathrm{~mm}$ long in distal half on each side; lateral lobes linear-lanceolate, $6.5-8 \mathrm{~mm}$ long, ascending-pubescent and with short glandular hairs towards apex. Corolla pale blue, 37 $42 \mathrm{~mm}$ long, pubescent externally with mixed glandular and eglandular hairs; tube 24 - $25 \mathrm{~mm}$ long, cylindrical and $3 \mathrm{~mm}$ wide below insertion point of stamens, gradually funnel-shaped distally, mouth 6 $8 \mathrm{~mm}$ wide; limb in weak " $4+1$ " configuration, abaxial lobe offset by $\pm 3 \mathrm{~mm}$, all lobes obovate, $11-14.5 \mathrm{~mm}$ long, abaxial and lateral lobes, 7.5 - $10 \mathrm{~mm}$ wide, apices rounded, adaxial lobes $7-8.5 \mathrm{~mm}$, apices with short attenuate tip. Stamens inserted $11.5-12.5 \mathrm{~mm}$ from base of corolla tube; filaments $21-23 \mathrm{~mm}$ long, pubescent at base; anthers $2.2-2.5 \mathrm{~mm}$ long; lateral staminodes with filaments $2.5-3 \mathrm{~mm}$ long, pubescent; antherodes well-developed, $0.7-0.9 \mathrm{~mm}$ long, bearing a few pollen grains; adaxial staminode $2.6 \mathrm{~mm}$ long, antherode absent. Ovary 3 - $3.5 \mathrm{~mm}$ long, glabrous; 
style c. $35 \mathrm{~mm}$ long, crisped-puberulent towards base, densely so at attachment point; stigma clavate, 0.6 $0.75 \mathrm{~mm}$ long. Capsule only seen in immature state, fusiform with very short beak, $12.5-13 \times 5 \mathrm{~mm}$ in face view, glabrous; seeds not seen. Fig. 2 .

RECOGNITION. Barleria ensermui has previously been confused with $B$. mucronifolia Lindau but clearly differs in corolla morphology: $B$. ensermui has a markedly shorter corolla tube $24-25 \mathrm{~mm}$ long (vs $33-40 \mathrm{~mm}$ long), with a shorter basal cylindrical portion below the insertion point of the stamens, this being 11.5 $12.5 \mathrm{~mm}$ from the base in B. ensermui (vs $17-24 \mathrm{~mm}$ from the base), and a more markedly funnel-shaped throat, and has larger and more divergent corolla lobes 11 - $14 \mathrm{~mm}$ long (vs 7 - $11 \mathrm{~mm}$ long, not markedly divergent). They also differ in the shape of the outer calyx lobes, those of $B$. ensermui being (oblong-) elliptic or obovate with base cuneate or attenuate (vs broadly ovate with cordate base) and in the posterior lobe having strictly marginal spines in the distal half (vs margin subentire or if spiny then spines in the proximal half being submarginal).

DISTRIBUTION. Barleria ensermui is currently known only from the type collection from Somaliland in northwest Somalia close to the Ethiopia border (Flora of Somalia region N1). Map 1, blue square.

SPECIMEN STUDIED. SOMALIA. Somaliland, plain on Buramo [Borama] - Hargeisa road, 28 miles $\mathrm{E}$ of Buramo, c. $9^{\circ} 40^{\prime} \mathrm{N}, 43^{\circ} 25^{\prime} \mathrm{E},[5200 \mathrm{ft}] 1580 \mathrm{~m}, \mathrm{fl} . \& \mathrm{fr}$. 13 Feb. 1933, Gillett 4999 (K, holotype \& isotype).

HABITAT \& ECOLOGY. Barleria ensermui was recorded from amongst grass in open Acacia woodland over gneiss at c. $1580 \mathrm{~m}$ elevation.

CONSERVATION STATUS. This species is known only from the type gathering made in 1933, when it was recorded as abundant at the type locality. Google Earth imagery shows that this area is now intensively farmed, with many strip-like fields clearly visible across the plains and gulleys, particularly south of the Buramo-Hargeisa road. This area has been farmed for at least 50 years (Ahmed Ibrahim Awale, pers. comm. via $H$. Pickering). In view of the significant habitat loss, this species may well be globally threatened, but with no recent information and with only one historical collection known, it must currently be considered Data Deficient (DD).

ETYMOLOGY. As noted in the introduction, this species is named in honour of Ensermu Kelbessa (1952 2016) to acknowledge his important contribution to African botany.

NOTES. Barleria ensermui falls within sect. Barleria and appears to be allied to other spiny species in this section from northeast Africa; it is compared to potential confusion species in Table 1. Hedrén (2006a) included it within B. mucronifolia but noted that "Gillett 4999 from N1 stands out by having large funnel-shaped flowers up to $25 \mathrm{~mm}$ across and more spiny calyx lobes with apical spine up to c. $12 \mathrm{~mm}$ long" (p. 429). The apical spine character does not appear to differentiate the two species, but the marked differences in corolla and calyx morphology clearly separate these two as distinct species (see Recognition section, and Table 1). B. mucronifolia, including B. homoiotricha C. B. Clarke which was the name used in Ensermu (2006), is widespread in the Horn of Africa and extends to Yemen.

The corolla morphology of Barleria ensermui is more reminiscent of B. steudneri C. B. Clarke from Eritrea, Ethiopia, Kenya, Sudan and Uganda. However, that species has longer, trailing-decumbent leafy stems with larger leaves 20 - $55 \mathrm{~mm}$ long and has markedly different calyces, the anterior and posterior lobes being broader (the latter $12-17 \mathrm{~mm}$ wide) and with a laciniate-toothed margin which is also conspicuously bristly-ciliate. B. steudneri also has shorter staminal filaments and larger anthers than B. ensermui (see Table 1).

A final species worthy of mention is Barleria delamerei S. Moore from southern Ethiopia, Kenya and northern Tanzania, which was recorded under its synonym B. spinisepala E. A. Bruce in Ensermu (2006). This species also has a similar corolla morphology but is easily separated from B. ensermui by, amongst other differences, having single-flowered inflorescences, linear or narrowly lanceolate bracteoles with a narrower blade, in usually having narrower, lanceolate to oblong-elliptic calyx lobes, 2 $-6 \mathrm{~mm}$ wide which if at the wider end of this range, are more regularly spiny along the margin, and in the external surface of the calyces and bracteoles lacking large short-stalked cup-shaped glands. $B$. delamerei is not known from Somalia - the record of B. spinisepala in Hedrén (2006a) is erroneous; see Darbyshire (2010).

Barleria baluganii Ensermu sp. nov. Type: Ethiopia, Welega Region, Kelem Awraja, c. $13 \mathrm{~km} \mathrm{~S}$ of Dambidollo on the way to Gambella, $1990 \mathrm{~m}$, fl. 18 Nov. 1981, Mesfin T. E Kagnew G. Y. 2347 (holotype ETH sheet 1; isotypes ETH sheet 2, K).

http:/ /www.ipni.org/urn:lsid:ipni.org:names:77167079-1

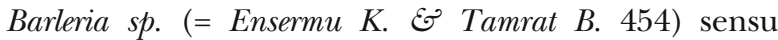
Ensermu (2006: 405).

Scrambling or climbing woody herb up to 2 - $5 \mathrm{~m}$ high; stems channelled, black or dark green (-brown) in dry state, glabrous except for some bristly hairs at the nodes and on distal-most internodes, these also with two lines of pale retrorse hairs; internodes $5-13 \mathrm{~cm}$ long. Leaves on petioles $4-30 \mathrm{~mm}$ long, glabrous or shortly pubescent above; blade ovate or ovate-elliptic, 


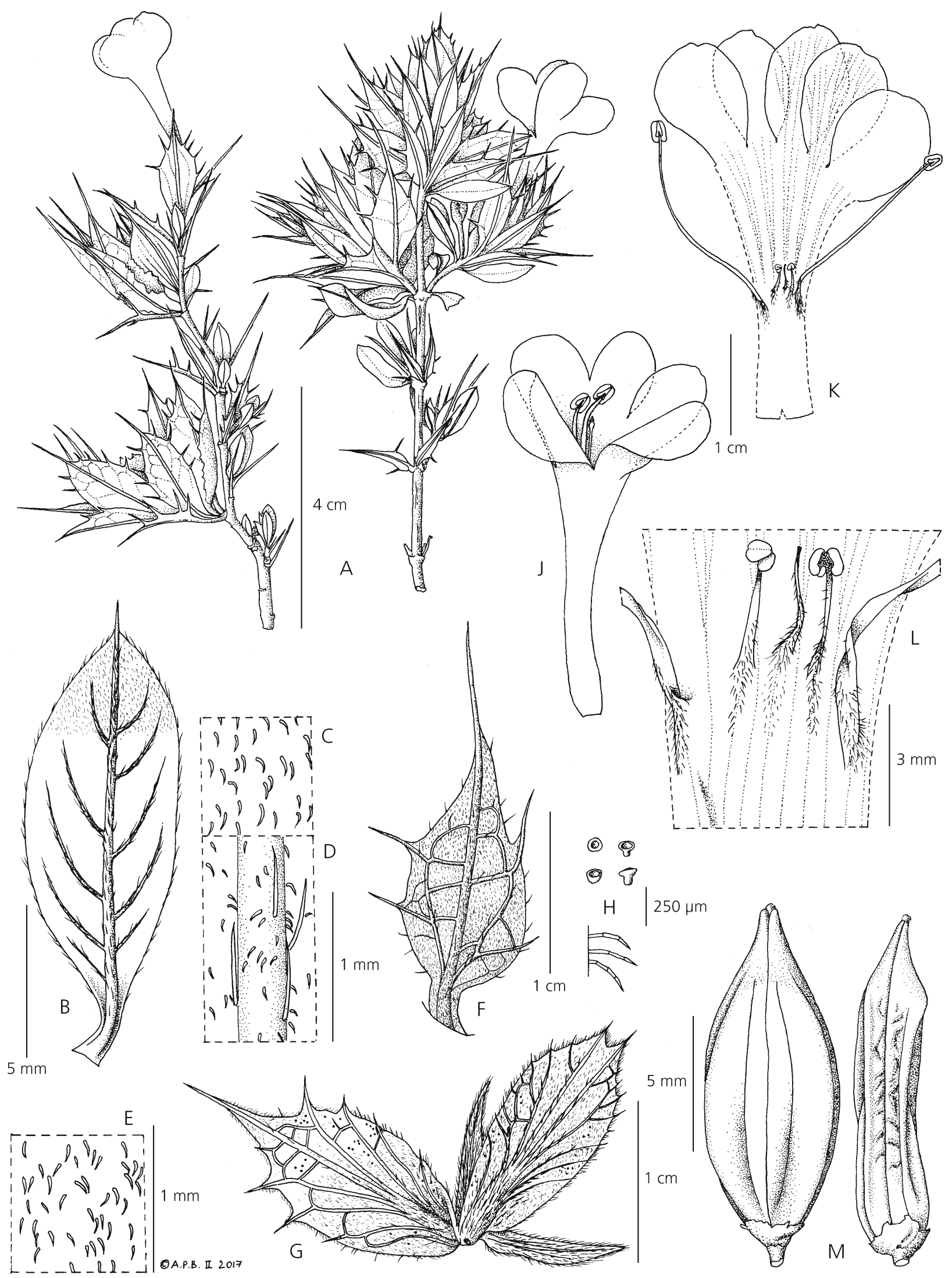


Fig. 2. Barleria ensermui. A habit, two flowering branches; $\mathbf{B}$ leaf, abaxial surface; $\boldsymbol{C}$ detail of retrorse hairs on abaxial leaf surface; $\mathbf{D}$ detail of long hairs along midrib on abaxial leaf surface; $\mathrm{E}$ detail of stem indumentum; $\mathrm{F}$ bracteole, external surface; $\mathbf{G}$ dissected calyx, external view; $\mathbf{H}$ detail of posterior calyx lobe hairs: multicellular marginal hairs, and cup-shaped glands from external surface; J flower; $\mathrm{K}$ dissected corolla with androecium; L detail of staminodes; $M$ capsule, face and lateral views. From Gillett 4999. DRAWN BY ANDREW BROWN.

$7-16 \times 3-6 \mathrm{~cm}$, broadest below the middle, base cuneate to attenuate, margins entire, apex short- or often long-acuminate, surfaces largely glabrous except for sparse appressed bristly hairs along main veins beneath and on margin, adaxial surface sometimes with scattered appressed hairs; lateral veins $5-6$ pairs, strongly ascending. Inflorescences of 3 - 7- or more (rarely 1 - 2- when young) flowered cymes borne in the upper leaf-axils and terminally, at $3-7$ nodes, the lower cymes alternate and distant, the upper opposite and condensed, together forming an interrupted terminal thyrse; bracts foliaceous but reducing rapidly up the thyrse, those in distal portion ovate-elliptic to narrowly elliptic, $15-28 \times 4-13 \mathrm{~mm}$, indumentum as that of leaves; bracteoles linear to narrowly oblanceolate, $4-12 \times 0.5-2 \mathrm{~mm}$ or those of first flowers in several-flowered cymes can be larger, oblanceolate or even elliptic, $10-15 \times 2-6 \mathrm{~mm}$, sparsely pubescent with bristly hairs mostly along margins, with or without few glandular hairs, or nearly glabrous. Calyx with lobes unequal, anterior lobe ovate-elliptic, $10-16 \times 4$ - $7 \mathrm{~mm}$, apex bifid with 0.5 - $4 \mathrm{~mm}$ long lobes; posterior lobe $11-17 \times 6-8 \mathrm{~mm}$, apex entire, acute to attenuate, both pubescent with bristly hairs, these appressed on external surface, longer and ascending along margin where sometimes bulbous-based and forming small teeth, external surface with or without sparse short spreading glandular hairs; lateral lobes linear-subulate, $9-12 \times 1.2-1.5 \mathrm{~mm}$, black along midrib, pubescent with ascending long bristly hairs. Corolla blue or pale lilac-blue, (35 -) 40 - 45 mm long; tube infundibuliform, $21-23 \mathrm{~mm}$ long, narrow proximal portion $9-10 \mathrm{~mm}$ long, $\pm 3 \mathrm{~mm}$ diam. at extreme base, glabrous, distal enlarged portion 12 $13 \mathrm{~mm}$ long, 10 - $11 \mathrm{~mm}$ diam. at mouth, this and lobes pubescent externally with glandular and eglandular hairs; limb in " $4+1$ " configuration, abaxial lobe offset by $10-11 \mathrm{~mm}$, obovate, $16-18 \times 19-$ $21 \mathrm{~mm}$ (c. $6 \mathrm{~mm}$ wide at base), apex emarginate; lateral and adaxial lobes subequal $12-14 \times 10-$ $15 \mathrm{~mm}$ ( $4-7 \mathrm{~mm}$ wide at base). Stamens 2 , inserted \pm $10 \mathrm{~mm}$ above base of corolla tube; filaments 24 $25 \mathrm{~mm}$ long, pubescent at base with glandular and eglandular hairs; anthers $\pm 3 \mathrm{~mm}$ long; staminodes 3 ,

Table 1. Comparison of the main diagnostic characters separating Barleria ensermui from allied species.

\begin{tabular}{|c|c|c|c|c|}
\hline Character & B. ensermui & B. mucronifolia & B. steudneri & B. delamerei \\
\hline Inflorescence & $\begin{array}{l}2 \text { - 6-flowered } \\
\text { contracted unilateral } \\
\text { cyme }\end{array}$ & $\begin{array}{l}(1-) 3-15 \text {-flowered } \\
\text { contracted unilateral cyme }\end{array}$ & $\begin{array}{l}\text { Several - many- } \\
\text { flowered } \\
\text { contracted uni- } \\
\text { lateral cymes }\end{array}$ & Flowers solitary \\
\hline $\begin{array}{l}\text { Bracteoles: shape } \\
\text { and width } \\
\text { (longer of each } \\
\text { pair, excluding } \\
\text { basal-most pair) }\end{array}$ & $\begin{array}{l}\text { Lanceolate with base } \\
\text { abruptly widened and } \\
\pm \text { rounded; } 4.5-9 \mathrm{~mm} \\
\text { wide excluding lateral } \\
\text { spines }\end{array}$ & $\begin{array}{l}\text { (Ovate-) lanceolate with base } \\
\text { usually rounded or obtuse; } \\
1.5-8.5 \mathrm{~mm} \text { wide } \\
\text { excluding (if present) } \\
\text { lateral spines }\end{array}$ & $\begin{array}{l}\text { Ovate to oblong- } \\
\text { lanceolate, } 7.5- \\
16 \mathrm{~mm} \text { wide }\end{array}$ & $\begin{array}{l}\text { Linear or narrowly } \\
\text { lanceolate, base cuneate; } \\
0.7-2(-3) \text { mm wide } \\
\text { excluding harsh lateral } \\
\text { spines }\end{array}$ \\
\hline $\begin{array}{l}\text { Posterior calyx } \\
\text { lobe: shape and } \\
\text { width }\end{array}$ & $\begin{array}{l}\text { (Oblong-) elliptic or } \\
\text { obovate, base cuneate } \\
\text { or attenuate; } 4.5- \\
11.5 \mathrm{~mm} \text { wide }\end{array}$ & $\begin{array}{l}\text { Broadly ovate, base cordate; } \\
9-17 \mathrm{~mm} \text { wide }\end{array}$ & $\begin{array}{l}\text { Ovate to elliptic, } \\
12-17 \mathrm{~mm} \text { wide }\end{array}$ & $\begin{array}{l}\text { Lanceolate, oblong or } \\
\text { elliptic, base cuneate; } 2 \text { - } \\
6 \mathrm{~mm} \text { wide }\end{array}$ \\
\hline $\begin{array}{l}\text { Posterior calyx } \\
\text { lobe: margin }\end{array}$ & $\begin{array}{l}\text { With } 2 \text { or } 3 \text { prominent } \\
\text { spines along each } \\
\text { margin in distal half }\end{array}$ & $\begin{array}{l}\text { Subentire or if spines } \\
\text { present then those in } \\
\text { proximal half are } \\
\text { submarginal }\end{array}$ & $\begin{array}{l}\text { Laciniate and with } \\
\pm \text { dense bristly } \\
\text { hairs }\end{array}$ & $\begin{array}{l}\text { With } 2-9 \text { spines along each } \\
\text { margin (plants with } \\
\text { elliptic calyces usually } \\
\text { have more than } 4 \text { spines } \\
\text { per margin) }\end{array}$ \\
\hline Corolla tube & $\begin{array}{l}24-25 \mathrm{~mm} \text { long, funnel- } \\
\text { shaped above inser- } \\
\text { tion point of stamens }\end{array}$ & $\begin{array}{l}33 \text { - } 40 \mathrm{~mm} \text { long, cylindrical } \\
\text { for most of length, shortly } \\
\text { funnel-shaped at mouth } \\
\text { only }\end{array}$ & $\begin{array}{l}25 \text { - } 34 \mathrm{~mm} \text { long, } \\
\text { narrowly funnel- } \\
\text { shaped above in- } \\
\text { sertion point of } \\
\text { stamens }\end{array}$ & $\begin{array}{l}18-27 \mathrm{~mm} \text { long, funnel- } \\
\text { shaped above insertion } \\
\text { point of stamens }\end{array}$ \\
\hline Corolla lobes & $\begin{array}{l}11-14.5 \mathrm{~mm} \text { long, } \\
\text { divergent at anthesis }\end{array}$ & $\begin{array}{l}7-11 \mathrm{~mm} \text { long, not widely } \\
\text { divergent at anthesis }\end{array}$ & $\begin{array}{l}13 \text { - } 19 \mathrm{~mm} \text { long, } \\
\text { divergent at } \\
\text { anthesis }\end{array}$ & $\begin{array}{l}8.5-13.5 \mathrm{~mm} \text { long, } \\
\text { divergent at anthesis }\end{array}$ \\
\hline $\begin{array}{l}\text { Staminal filament } \\
\text { length }(\mathrm{mm})\end{array}$ & $21-23$ & $15-21$ & $12-18$ & $10-22$ \\
\hline $\begin{array}{l}\text { Anther length } \\
(\mathrm{mm})\end{array}$ & $2.2-2.5$ & $2-2.8$ & $3-3.8$ & $2-2.5$ \\
\hline
\end{tabular}


filaments $\pm 3 \mathrm{~mm}$ long, pilose with eglandular hairs; antherodes of lateral staminodes $\pm 1 \mathrm{~mm}$ long, adaxial staminode without antherode. Ovary $\pm 3 \mathrm{~mm}$ long, surrounded by disc for up to half its length, glabrous; style $\pm 35 \mathrm{~mm}$ long, glabrous; stigma clavate to subcapitate, 0.6 - $0.8 \mathrm{~mm}$ long. Capsule (obovate-) elliptic in face view, $12-15 \times 6-8 \mathrm{~mm}$, shining black, glabrous, 2-seeded; seeds $6-7 \times 5-6 \mathrm{~mm}$, face subovate, with dark golden-yellow to brown hygroscopic hairs in dry state, shining. Figs $3 \& 4$.

RECOGNITION. Barleria baluganii is closely related to $B$. ventricosa Hochst. ex Nees and allies. It differs from B. ventricosa sensu stricto and B. vix-dentata $C$. B. Clarke (sometimes treated as a form of B. ventricosa) in that it dries dark green or green-brown with often blackish stems (vs usually drying bright green or greyish-green); in the vegetative parts being near-glabrous (vs conspicuously hairy); in usually having long-acuminate leaves (vs leaves acute, attenuate or at most shortly acuminate), in the individual cymes of the thyrse having $3-7$ or more flowers (vs $1-3$ flowers), and in the indumentum on the external calyx surface being sparser and more appressed. The "keniensis" form of $B$. ventricosa often dries blackish and can have more markedly acuminate leaves and more than 3 flowers per cyme as in B. baluganii, but the new species differs in being less hairy throughout and in particular lacking the dense silky indumentum of the calyces, bracts and young shoots, and in having more unequal anterior and posterior calyx lobes.

DISTRIBUTION. Baleria baluganii occurs in the Welega, Ilubabor and Kefa Floristic Regions of southwestern Ethiopia. Map 1, black circles.

SPECIMENS STUDIED. ETHIOPIA. Welega Region: Anfilo, near Dambidolla, $6300 \mathrm{ft}[1920 \mathrm{~m}]$, fl. \& fr. 3 March 1957, Mooney 6873 (ETH, K); about $15 \mathrm{~km} \mathrm{E}$ of Nekemte, $9^{\circ} 05^{\prime} \mathrm{N}, 36^{\circ} 35^{\prime} \mathrm{E}, 1910 \mathrm{~m}, 23$ Oct. 1980, Ensermu K. E् Tamrat B. 454 (ETH); Kelem Awraja, c. $13 \mathrm{~km} \mathrm{~S}$ of Dembidollo on the way to Gambella, 1990 m, fl. 18 Nov. 1981, Mesfin T. E Kagnew G. Y. 2347 (ETH holotype; ETH, K isotypes); $78 \mathrm{~km}$ from Gimbi to Dembidollo, $1700 \mathrm{~m}$, fl. 27 Oct. 1985, Sebsebe D. $\mathcal{E}^{\circ}$ Ensermu K. 1580 (ETH). Ilubabor Region: around Gumuro tea plantation, 1750 m, fl. \& fr. 9 Jan. 1978, Mesfin T. E Sebsebe D. 194 (ETH); Gore Awraia, at/ between Gumaro R. and Gumaro Tea Plantation, $8^{\circ} 09^{\prime} \mathrm{N}, 35^{\circ} 28^{\prime} \mathrm{E}, 1700-1730 \mathrm{~m}$, fl. 12 Aug. 1982, Puff E Ensermu K. 820812-4/3. (ETH, WU). Kefa Region: Jimma, fl. Oct. 1954, Mooney 5929 (ETH, K); Jimma, fl. 11 Sept. 1958, Siegenthalier X-52 (K); E side of Bellete Forest, $6800 \mathrm{ft}$ [2070 m], fl. 9 Sept. 1962, Palmer 63A (K); $49 \mathrm{~km} \mathrm{~N}$ of Jimma, via Agaro road, turning right at Ghembi village, thence NW c. $8 \mathrm{~km}, 7^{\circ} 57^{\prime} \mathrm{N}$, $36^{\circ} 48^{\prime} \mathrm{E}, 1610 \mathrm{~m}$, fl. 24 Nov. 1964, Meyer 8824 (K); about $10 \mathrm{~km}$ E of Jimma, $2000 \mathrm{~m}$, fl. 12 Aug. 1965, de Wilde Ẽ de Wilde-Duyfjes 7627 (ETH, K, WAG); between
Fig. 3. Barleria baluganii. A habit, flowering branch; B calyx, anterior lobe folded down; $\mathrm{C}$ dissected corolla with stamens and staminodes; D detail of staminodes; $\mathbf{E}$ fertile stamens; $\mathbf{F}$ gynoecium with disc; $\mathrm{G}$ detail of stigma with uppermost portion of style; $\mathrm{H}$ capsule within persistent calyx, dehisced; J seed. A - G from Mesfin T. \& Kagnew 2347, H \& J from Mooney 6873. DRAWN BY LINDA GURR.

Wush-Wush and Buba, c. $20 \mathrm{~km}$ NW of Bonga, c. 1800 m, fl. 17 Aug. 1965, de Wilde Ẽ de Wilde-Duyfjes 7779 (ETH, K, WAG); Bellete Forest, c. $40 \mathrm{~km}$ SW of Jimma, on Bonga road, $7^{\circ} 35^{\prime} \mathrm{N}, 36^{\circ} 38^{\prime} \mathrm{E}, 2000 \mathrm{~m}$, fl. 10 Nov. 1970, Friis, Hounde A. E Jacobsen 237 (C, ETH, $\mathrm{K})$; Bonga, behind the Catholic Mission, $7^{\circ} 15^{\prime} \mathrm{N}$, $36^{\circ} 13^{\prime} \mathrm{E}, 1700 \mathrm{~m}$, fl. 6 Jan. 1973, Friis et al. 2091 (C, ETH, K); $65 \mathrm{~km} \mathrm{~W}$ of Bonga along road to Shewa Gimira, $7^{\circ} 15^{\prime} \mathrm{N}, 35^{\circ} 55^{\prime} \mathrm{E}, 1600 \mathrm{~m}$, fl. 11 Jan. 1973, Friis et al. 2199 (C, ETH, K); Kefa Awraja, Bonga area, $7^{\circ} 15^{\prime} \mathrm{N}, 36^{\circ} 15^{\prime} \mathrm{E}, 1700$ - $1800 \mathrm{~m}$, fl. 16 Aug. 1982, Puff Eं Ensermu K. 820816-3/4 (ETH, K, WU); Jimma Awraja, E end of Belleta Forest, $7^{\circ} 35^{\prime} \mathrm{N}, 36^{\circ} 40^{\prime} \mathrm{E}, 2170$ m, fl. 18 Aug. 1982, Puff E Ensermu K. 820818-7/3 (ETH, K, WU); Bebeka Coffee Plantation, S of Mizan Teferi, $5 \mathrm{~km}$ NE of the Coffee Plantation H.Q., $6^{\circ} 54$ 'N, $35^{\circ} 27^{\prime E}, 1150$ m, fl. \& fr. 3 Nov. 1984, Friis, Gilbert $\mathcal{E}^{\circ}$ Vollesen 3971 (C, ETH, K); $40 \mathrm{~km}$ to SW from Jima, on the way to Gojeb, near Forest Station, 2100 m, fl. 20 April 1997, Pavlov 97-142 (ETH); SW of Jimma on main road $10 \mathrm{~km}$ before Bonga, $7^{\circ} 17^{\prime} \mathrm{N}, 36^{\circ} 17^{\prime} \mathrm{E}$, fl. 16 Sept. 2003, Brummitt 20929 (K); Bonga, near Barta Waterfall just outside of town, $1870 \mathrm{~m}$, fl. 10 April 2010, Tripp [with Ensermu K.] 915 (ETH, RSA).

HABITAT \& ECOLOGY. Barleria baluganii occurs in areas of moist forest of e.g. Pouteria, Albizia, Olea, Schefflera and Dracaena, sometimes with Croton macrostachyus Delile and Cordia africana Lam. It typically occurs in dense thickets along forest streams, margins, clearings or in disturbed secondary growth where it can clamber over and within other bushes and small trees. It can also occur in coffee plantations where the coffee is shade-cropped within semi-natural forest, where it can be found clambering over Coffea arabica L. It occurs at $(1100-) 1600-2200 \mathrm{~m}$ altitude.

CONSERVATION STATUS. This species occurs only in the upland forest zone of western Ethiopia betwen Gambela and Jimma west to east and between Nekemte and Mizan Teferi north to south. It has an EOO of $39,934 \mathrm{~km}^{2}$ and an AOO of $80 \mathrm{~km}^{2}$, applying the standard $2 \times 2 \mathrm{~km}$ grid cell size recommended for AOO calculation (IUCN Standards and Petitions Subcommittee 2017). It can be locally common in suitable habitat. However, these forests are under increasing threat from a range of pressures including expanding plantation agriculture, exotic tree forestry and timber extraction (BirdLife International 2017a \& b; Sebsebe Demissew, pers. comm.). Several historical 


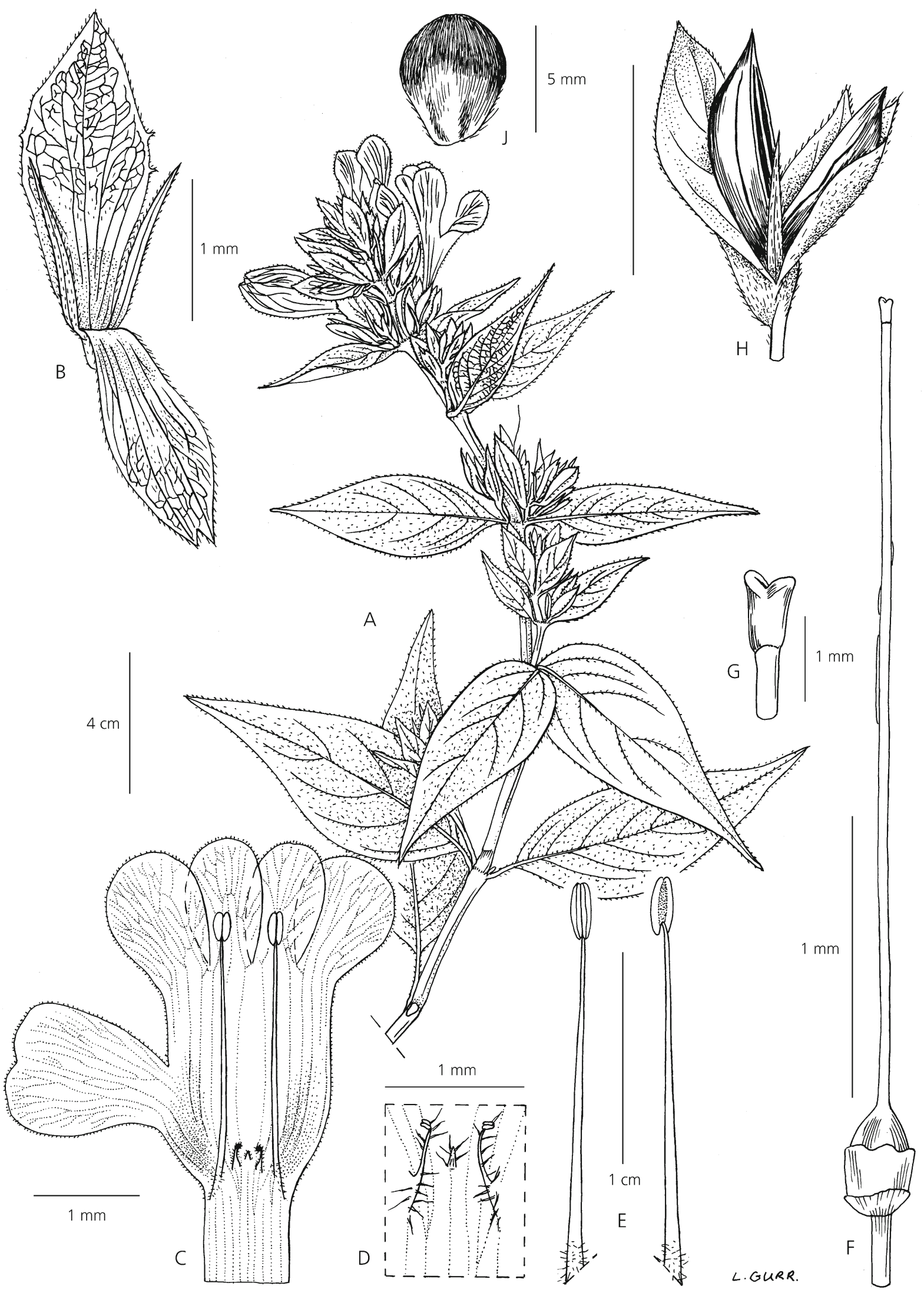




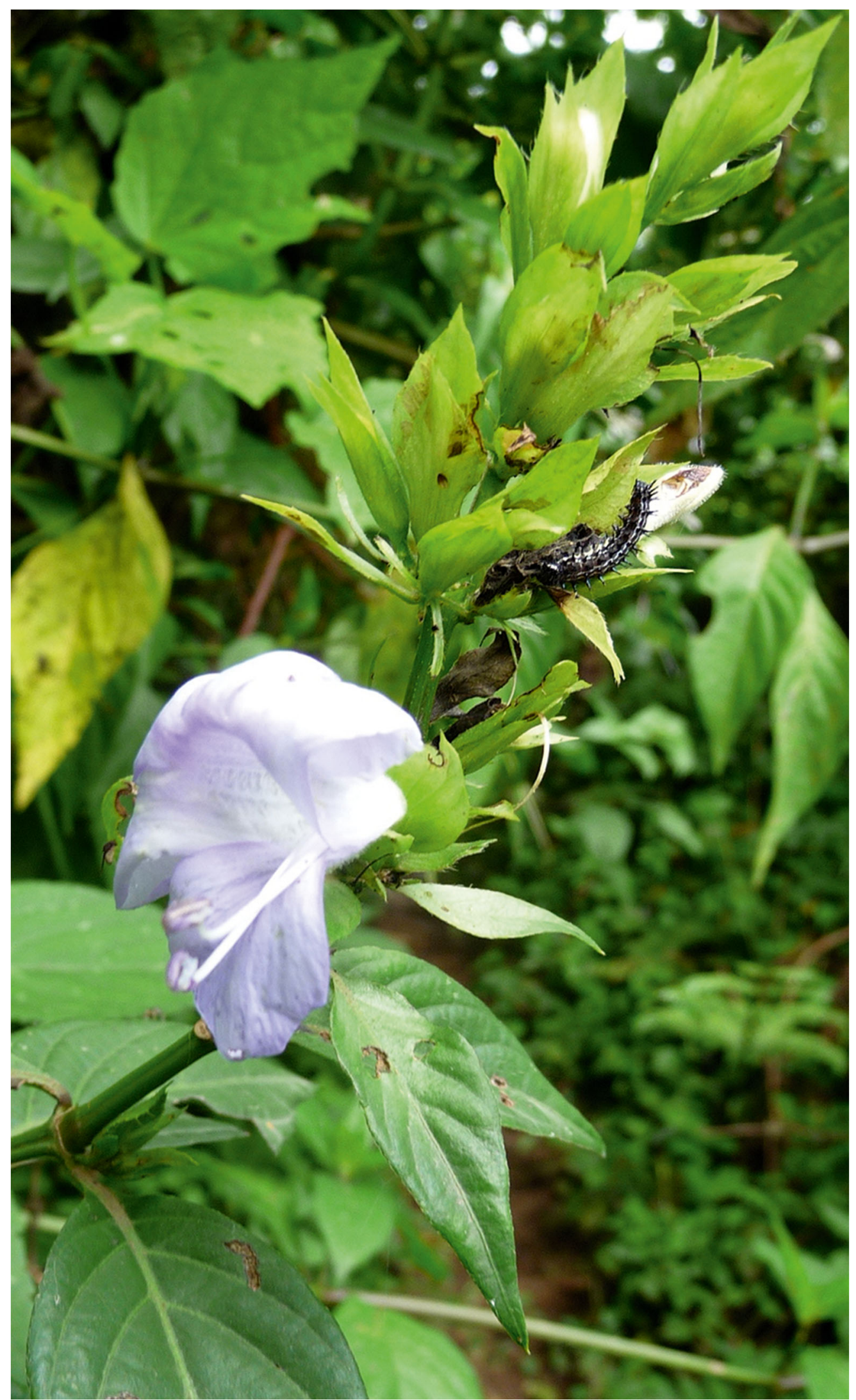

Fig. 4. Barleria baluganii photographed near Barta Waterfall, Ethiopia, $10^{\text {th }}$ April 2017. PHOTO: E. A. TRIPP. 
sites for this species now appear, from Google Earth imagery, to have little or no forest remaining. It is therefore possible that this species would qualify as threatened under IUCN criterion A, but for a full assessment, the generation length and rates of decline would need to be better understood. In the absence of such information, this species is considered to be Near Threatened (NT) as it is close to qualifying as Vulnerable under IUCN criterion B2 but with more than 10 locations currently known.

ETYMOLOGY. The species epithet was proposed by Ensermu (pers. comm.) to commemorate Luigi Balugani (1737 - 1770), Italian artist from Bologna, who served as an assistant and artist to the Scottish explorer James Bruce during their journey in Ethiopia in $1769-1770$, during which Balugani was the first to study the Ethiopian flora and make meticulous drawings and observations according to contemporary scientific ideas.

NOTES. With the combination of 2-seeded capsule lacking a prominent beak, simple indumentum, lack of spines and infundibuliform corolla with " $4+1$ " limb configuration, this species would previously have been placed within Barleria sect. Fissimura M. Balkwill (Balkwill \& Balkwill 1997; Darbyshire 2009). However, recent molecular evidence (Fisher et al., unpubl. data) indicates that sect. Fissmura is nested within sect. Barleria and so cannot be upheld. B. baluganii is allied to the $B$. ventricosa Nees complex; this group was treated as an aggregate species with only informally recognised taxa in Flora of Tropical East Africa (Darbyshire 2010 - see discussion on p. 363) whereas in FEE the taxa were maintained as good species (Ensermu 2006). It is on the latter basis that B. baluganii is recognised as a distinct species, and this is well justified by the fact that the different entities are clearly discrete in Ethiopia. Indeed, B. baluganii is quite distinctive in general gestalt, and can be separated from all forms of $B$. ventricosa sensu lato when the combination of the following characters is observed: the largely glabrous vegetative parts that dry dark green to green-brown (stems often drying black), the \pm long-acuminate leaves, the well-developed terminal thyrse with cymes often more than 3-flowered, and the rather sparse appressed calyx indumentum. It should be noted, however, that none of these characters are wholly diagnostic when taken in isolation. A detailed molecular study is required on the $B$. ventricosa complex to assist with species delimitation, but $B$. baluganii appears to be sufficiently distinct morphologically to warrant recognition at this stage.

The only other potential confusion species is Barleria brownii S. Moore which also occurs in the forests of Kefa region, although at slightly lower altitudes $( \pm 1050 \mathrm{~m})$, and shares with $B$. baluganii an interrupted terminal thyrse. However, B. brownii is unmistakable in flower, having extremely long- exserted stamens and stigmas, the staminal filaments being $34-65 \mathrm{~mm}$ long and the style similarly long.

Barleria baluganii is one of several forest acanths restricted to the moist forests of western and southern Ethiopia; other examples include Brillantaisia grotanellii Pic. Serm., Justicia bizuneshiae Ensermu and the recently described Acanthopale aethio-germanica Ensermu (Ensermu 2006, 2009).

Barleria ferox Ensermu $\mathcal{E}$ I. Darbysh. sp. nov. Type: Ethiopia, Harerge Region, near Galacia, 10 Nov. 1963, Burger 3349 (holotype ETH; isotypes FT, K).

http://www.ipni.org/urn:lsid:ipni.org:names:77167080-1

Barleria sp. (= Amare G. D-10) sensu Ensermu (2006: 415).

Harshly spiny shrub up to $0.3-1 \mathrm{~m}$ high; muchbranched; stems at first 4-angular and -ridged, later becoming more convex between the ridges, mature stems stout, to $5-9 \mathrm{~mm}$ diam., internodes mostly short with crowded nodes, internodes of leafy stems up to $30 \mathrm{~mm}$ long; young stems puberulous in two opposite bands in shallow channels between the ridges, shortly strigulose around the nodes and along the nodal line. Axillary spines white-grey, stout, stalk (4-) 8 - $16 \mathrm{~mm}$ long; 4-rayed, longest rays typically 22 - $32 \mathrm{~mm}$ long, straight and widely divergent. Leaves on petiole up to $5 \mathrm{~mm}$ long; blade somewhat coriaceous, oblong-elliptic or -obovate, $27-48 \times 13-25 \mathrm{~mm}$, conduplicate in dry state, base cuneate, margin entire, apex mucronate with $2-3 \mathrm{~mm}$ long spine, sparsely strigulose along main veins beneath, margin and midrib above, also with \pm numerous broad sessile glands towards base beneath; lateral veins indistinct, 4 - 6 pairs. Inflorescences terminal, spiciform or conical in outline, with a series of decussately arranged cymes, often 3-flowered but those towards apex of inflorescence 1-flowered, cymes at base of inflorescence can have 7 or more flowers, dichasial, lateral branches partially fused to subtending bracteoles; bracts leafy but reducing in size and width up the axis, elliptic to obovate-elliptic or narrowly so, typically $18-30 \times 3.5-$ $13 \mathrm{~mm}$, apex long-spinose, abaxial surface with numerous broad sessile glands towards base; bracteoles linear-lanceolate, varying considerably in size, typically $10-17.5 \times 1.5-3 \mathrm{~mm}$, but with those subtending first flower of dichasial cymes up to $24-$ $29 \mathrm{~mm}$ long, those of cymes towards apex of inflorescence can be much-reduced, then $5 \times 0.5 \mathrm{~mm}$ or less, well-developed bracteoles with apex long-spinose, midrib prominent, abaxial surface with numerous broad sessile glands towards base. Calyx at first drying brown with thin margins, these thickening and becoming white at fruiting stage, anterior and posterior lobes broadly ovate $2.7-3 \times 2-3 \mathrm{~mm}$ in flower 
excluding linear apical seta $1.5-2.5 \mathrm{~mm}$ long, this rarely bifid on anterior lobe, somewhat larger in fruiting stage where outer lobes up to $4.3 \times 4 \mathrm{~mm}$ excluding setae, external surface with scattered to numerous broad sessile glands, basal tubular portion often puberulent; lateral lobes lanceolate, more gradually narrowed into apical seta, $4-6 \times 1-2 \mathrm{~mm}$. Corolla 25 - $33 \mathrm{~mm}$ long, lilac- to blue-purple, glabrous externally; tube subcylindrical, $12-14 \mathrm{~mm}$ long, \pm 2.5 $-3 \mathrm{~mm}$ diam. at base, $\pm 3.5-4 \mathrm{~mm}$ at mouth; limb 5lobed in a weak " $4+1$ " configuration, abaxial lobe offset by $\pm 2.5 \mathrm{~mm}$, all lobes obovate, $13-15 \times 8-11$ $\mathrm{mm}$, rounded at apices, adaxial pair of lobes somewhat narrower than lateral and abaxial lobes. Stamens inserted $\pm 5-6.5 \mathrm{~mm}$ above base of corolla tube; filaments $\pm 20-25 \mathrm{~mm}$ long, sparsely pubescent proximally; anthers $3-3.5 \mathrm{~mm}$ long; lateral staminodes with filaments $\pm 2-2.7 \mathrm{~mm}$ long, pubescent, antherodes well-developed, 2-thecous, to $1 \mathrm{~mm}$ long. Ovary $4-4.5 \mathrm{~mm}$ long, glabrous; style 18 $22 \mathrm{~mm}$ long, glabrous; stigma linear, 0.8 - $1 \mathrm{~mm}$ long. Capsule only seen in immature state, 2-seeded, \pm $10 \mathrm{~mm}$ long including prominent conical beak, glabrous. Fig. 5.

RECOGNITION. Barleria ferox is morphologically closest to B. quadrispina, sharing with that species the combination of rayed axillary spines and blue or purple corollas arranged in decussate, dichasial cymes. It clearly differs in (1) having very stout axillary spines which are stalked for $(4-) 8-16 \mathrm{~mm}$ and have widely divergent rays (vs in $B$. quadrispina axillary spines slender and needle-like, often subsessile or stalked for less than $5 \mathrm{~mm}$, or if rarely stalked up to $12 \mathrm{~mm}$ then the rays ascending, much less divergent); (2) in having numerous and conspicuous broad sessile glands towards the base of the bracts and bracteoles and on the outer calyx lobes (these absent or sparse and inconspicuous in B. quadrispina) and (3) in the calyces being markedly shorter and broader, the lobes $4-6 \mathrm{~mm}$ long, the anterior and posterior lobes being broadly ovate and abruptly narrowed into a short linear seta (vs at least the posterior lobes markedly longer, 6.5 $17 \mathrm{~mm}$ long and usually over $10 \mathrm{~mm}$ long, basal portion not so broadly ovate and less abruptly narrowed into a long flexible apical seta). In addition, B. quadrispina is a less robust plant than B. ferox, and it usually has a conspicuously hairy inflorescence, with appressed to ascending, often bulbous-based bristly eglandular hairs and often also spreading slender glandular hairs which are absent in B. ferox. See Table 2.

DISTRIBUTION. Barleria ferox is distributed in eastern Ethiopia in Harerge Floristic Region. Map 1, black stars.

SPECIMENS STUDIED. ETHIOPIA. Harerge region: Jijiga Road, 15 Sept. 1958, Amare G. D-10 (EA, K); 90 km S of
Harar on road S of Midaga, 14 Oct. 1962, Burger 2190 (ETH, K); near Galalcia, 8²' N, 42 41 'E, 10 Nov. 1963, Burger 3349 (ETH holotype; FT, K isotypes).

HABITAT \& ECOLOGY. There is only very limited information on the ecology of Barleria ferox; on the type specimen it was recorded from open limestone slopes with shrubs and no trees, whilst Amare Getahun recorded it from a "dry area"; it occurs at c. $1400-$ 1600 m elevation.

CONSERVATION STATUS. This species is currently known from a very small range south of Harar and Jijiga in eastern Ethiopia, with three locations known and an EOO of $1348 \mathrm{~km}^{2}$, which falls within the Endangered range threshold for IUCN Criterion B1. It is clearly uncommon in view of the fact that it has not been collected for over half a century despite being a robust plant with showy flowers. Google Earth imagery shows that there is some fairly intensive agriculture in the region, particularly south of Midaga. It is considered likely that this has impacted on this species' habitat leading to some population decline. This species is therefore provisionally assessed as Endangered EN Blab(iii). However, it should be noted that parts of its range have not been intensively botanised and so it may prove to be more frequent within its small range than is currently known. Dedicated field surveys to rediscover this species and review its current status and population size are highly desirable.

ETYMOLOGY. The epithet "ferox", meaning "fierce", refers to the harshly spiny nature of this species.

NOTES. The combination of rayed axillary spines, an androecium comprising two perfected stamens and two lateral staminodes with well-developed antherodes, and a prominently beaked, 2-seeded capsule clearly place this species in Barleria sect. Prionitis (Oerst.) Nees (Balkwill \& Balkwill 1997; Darbyshire 2009). Blue to purple flowers are unusual in sect. Prionitis, where the flowers are typically yellow, orange, ochre-coloured, red or white. However, B. quadrispina Lindau, a widespread species in the drylands of the Horn of Africa, also has blue or purple (or white) corollas and B. ferox is undoubtedly close to that species, also sharing a similar inflorescence form in which at least some of the partial inflorescences are dichasial cymes with the lateral branches partially fused to the subtending bracteoles. Whilst B. quadrispina is quite a variable species, B. ferox is always easily separated from it by the characters listed in the Recognition section. The two are compared in Table 2, together with a third blue-flowered species, B. negeleensis which is described below.

The general habit including the harsh spines and the short, broadly ovate calyces in Barleria ferox are somewhat reminiscent of B. trispinosa (Forssk.) Vahl which occurs in northern Ethiopia, but that species is easily separated by its large yellow, orange or white corollas 40 - $60 \mathrm{~mm}$ long with a marked " $4+1$ " 


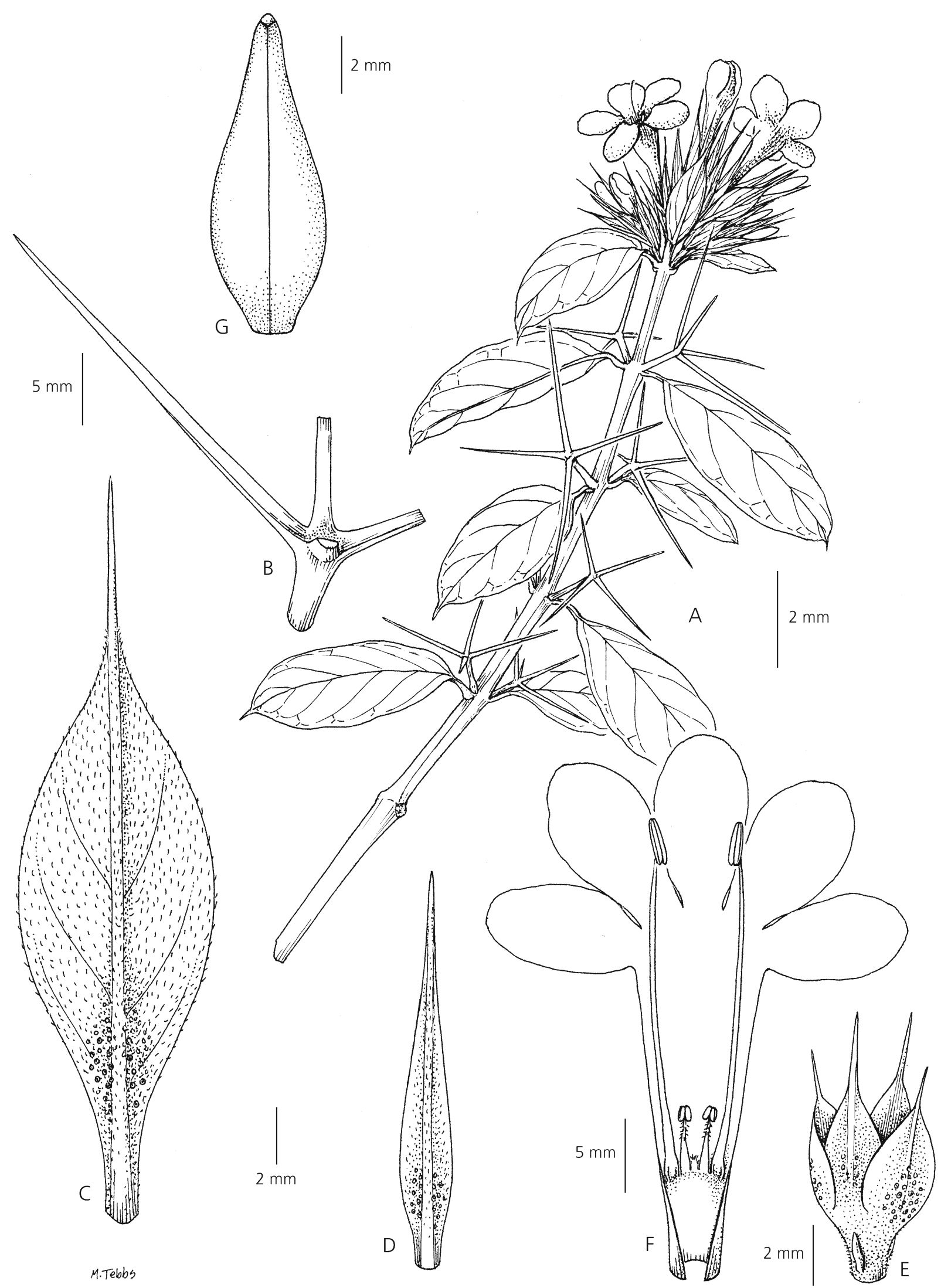

Fig. 5. Barleria ferox. A habit, fertile branch; B detail of axillary spine, 3 branches cut; C bract, external surface; D bracteole, external surface; E calyx; F dissected corolla with androecium; G immature capsule. A - F from Burger 3349; G from Burger 2190. DRAWN BY MARGARET TEBBS. 
Table 2. Comparison of the main diagnostic characters separating Barleria ferox, B. quadrispina and B. negeleensis. Note that only immature capsules have been seen for $B$. ferox.

\begin{tabular}{|c|c|c|c|}
\hline Character & B. ferox & B. quadrispina & B. negeleensis \\
\hline Rayed spines: stalk & Stout, $(4-) 8-16 \mathrm{~mm}$ long & $\begin{array}{l}\text { Often subsessile, if stalk present then } \\
\text { slender, to } 12 \mathrm{~mm} \text { long }\end{array}$ & $\begin{array}{l}\text { (If spines present) slender, } \\
0-12 \mathrm{~mm} \text { long }\end{array}$ \\
\hline Rayed spines: rays & $\begin{array}{l}\text { Stout, widely divergent, } \\
\text { longest ray } 22-32 \mathrm{~mm}\end{array}$ & $\begin{array}{l}\text { Slender, often ascending, longest ray } \\
10-29 \mathrm{~mm}\end{array}$ & $\begin{array}{l}\text { Slender, erect to divergent, } \\
\text { longest ray } 10-30 \mathrm{~mm}\end{array}$ \\
\hline Leaf shape and base & $\begin{array}{l}\text { Oblong-elliptic or -obovate, } \\
\text { base cuneate, shortly } \\
\text { petiolate }\end{array}$ & $\begin{array}{l}\text { Oblanceolate, obovate or oblong-elliptic; } \\
\text { base cuneate or attenuate, } \\
\text { shortly petiolate or if sessile then not } \\
\text { sheathing }\end{array}$ & $\begin{array}{l}\text { Linear-oblong to narrowly } \\
\text { oblong-elliptic, base sessile } \\
\text { and shortly sheathing the } \\
\text { stem }\end{array}$ \\
\hline Bract apex & $\begin{array}{l}\text { Apex with a long } \pm \text { stout } \\
\text { spine }\end{array}$ & Apex with a short slender spine & Apex with a long stout spine \\
\hline $\begin{array}{l}\text { Sessile cupular glands on } \\
\text { bracteoles and calyces }\end{array}$ & Numerous, conspicuous & Absent or sparse and inconspicuous & Absent \\
\hline $\begin{array}{l}\text { Anterior and posterior } \\
\text { calyx lobe shape and } \\
\text { dimensions (flowering } \\
\text { stage) }\end{array}$ & $\begin{array}{l}\text { Broadly ovate with a short } \\
\text { linear apical seta, } 4-5.5 \\
\quad \times 2-3 \text { mm including seta }\end{array}$ & $\begin{array}{l}\text { Lanceolate or ovate, } \pm \text { abruptly narrowing } \\
\text { into flexuose apical spine, }(5.5-) \\
10-17 \times 1.5-3(-4) \mathrm{mm}\end{array}$ & $\begin{array}{l}\text { Lanceolate, gradually (sub) } \\
\text { attenuate into apical spine } \\
(11-) 14-17 \times 4-6 \mathrm{~mm}\end{array}$ \\
\hline Capsule length & $\begin{array}{l} \pm 10 \mathrm{~mm} \text { (only seen in } \\
\text { immature state) }\end{array}$ & $9-11 \mathrm{~mm}$ & $13.5-16 \mathrm{~mm}$ \\
\hline Seed width (face view) & Unknown & $2.5-4 \mathrm{~mm}$ & $\pm 6.5 \mathrm{~mm}$ \\
\hline
\end{tabular}

configuration, the abaxial lobe being offset from the remaining lobes by over $10 \mathrm{~mm}$, and in the partial inflorescences being single-flowered.

Barleria negeleensis Ensermu $\mathcal{E} I$. Darbysh. sp. nov. Type: Ethiopia, Sidamo Region, Borana, $31 \mathrm{~km}$ from Negele towards Filtu, 14 Dec. 1990, Sebsebe D. E Ensermu K. 2658 (holotype ETH; isotype K).

http://www.ipni.org/urn:Isid:ipni.org:names:77167081-1

Barleria sp. (=Sebsebe D. E E Ensermu K. 2658) sensu Ensermu (2006: 416).

Spiny perennial herb, stems up to $40 \mathrm{~cm}$ long, creeping for most of their length but fertile portions decumbent, woody at base, mature stems stout, $4.5-7 \mathrm{~mm}$ diam., bluntly 4-angular and with 4 ridges, bearing prominent scars from leaf bases; young stems pubescent with long ascending bristly hairs or sparsely so, mature stems can be glabrescent; internodes variable, up to $3-4 \mathrm{~cm}$ long but can be very short or largely absent in some parts of the stems. Axillary spines present or absent, can be partially hidden by sheathing leaf base, pale grey, slender, stalk 0 - 12 mm long, usually 4-rayed (but those in distal leaf axils can be \pm sessile and 2-rayed, resembling bracteoles), rays erect to spreading; longest rays $10-30 \mathrm{~mm}$ long, glabrous or sparsely glandular-pubescent. Leaves sessile with base shortly sheathing stem; blade typically drying yellowish-green, linear-oblong to narrowly oblongelliptic, $5-14 \times 1-2.7 \mathrm{~cm}$, base cuneate, margin entire, apex acute or obtuse and with sharp spine 1 $3 \mathrm{~mm}$ long on cauline leaves or up to $8 \mathrm{~mm}$ long on leaves subtending inflorescences (these transitional to bracts), surfaces pubescent with bristly ascending hairs at least along margin, sometimes dense on margin, midrib and on main veins beneath; cystoliths very numerous and conspicuous; lateral veins $4-5$ pairs, these and midrib typically dry yellow, prominent beneath. Inflorescences terminal, densely spiciform with imbricate bracts, conical or subcapitate in outline, 3.5 - $11 \mathrm{~cm}$ long, with a series of decussately arranged dichasial cymes 3 - several-flowered, lateral branches partially fused to subtending bracteoles; bracts pale green or distal portion purple-tinged, bracts towards base of spike ovate to oblong-elliptic, $22-40 \times 8.5-$ $17 \mathrm{~mm}$ including prominent grey apical spine 4 $8 \mathrm{~mm}$ long; bracts towards apex of inflorescence becoming oblanceolate, then (14-) $18-31 \times(4-)$ $5.5-7.5 \mathrm{~mm}$, bracts at first \pm densely pubescent with ascending bristly eglandular hairs and long patent glandular hairs, but becoming glabrescent at fruiting stage; bracteoles variable, those of first flower in dichasium lanceolate to oblanceolate and can resemble the bracts, $15-32 \times(2-) 4-7.5 \mathrm{~mm}$, those of lateral flowers in dichasium more linear-lanceolate, $(8$ -) $14-20 \times 1-2.5 \mathrm{~mm}$, apex spinose, colour and indumentum as bracts. Calyx straw-coloured, anterior and posterior lobes sub-equal, lanceolate, (11 -) 14 $17 \times 4-6 \mathrm{~mm}$, apex (sub)attenuate into a spine, external surface densely pubescent with long bristly ascending or appressed eglandular hairs and long patent glandular hairs, becoming more sparse at fruiting; lateral lobes linear-lanceolate, $11-15 \times 1-$ 
$1.8 \mathrm{~mm}$. Corolla pale blue to purple, glabrous externally; tube \pm cylindrical $15-16 \mathrm{~mm}$ long, slightly swollen at the base where $\pm 3 \mathrm{~mm}$ diam., mouth \pm $2.5 \mathrm{~mm}$ diam.; limb in weak " $4+1$ " configuration, abaxial lobe offset by $\pm 2.5 \mathrm{~mm}$, lobes sub-equal, obovate, 14.5 - $21 \mathrm{~mm}$ long, abaxial and lateral lobes $10-14 \mathrm{~mm}$ wide, lateral lobes somewhat narrower, apices rounded. Stamens inserted $\pm 5-6 \mathrm{~mm}$ above base of corolla tube, exserted from tube for $\pm 12 \mathrm{~mm}$; filaments $17-21 \mathrm{~mm}$ long, shortly pubescent with blunt hairs; anthers $2.5-3 \mathrm{~mm}$ long; lateral staminodes borne above insertion point of stamens; filaments $1.3-2 \mathrm{~mm}$ long, pubescent proximally; antherodes $0.7-0.8 \mathrm{~mm}$ long; adaxial staminode minute or absent. Ovary c. $3 \mathrm{~mm}$ long, glabrous; style 27 - $29 \mathrm{~mm}$ long, glabrous; stigma linear, $0.5-0.6 \mathrm{~mm}$ long. Capsule $13.5-16 \times 6 \mathrm{~mm}$ including short beak $3.5-4 \mathrm{~mm}$ long, glabrous; seeds $\pm 8 \times 6.5 \mathrm{~mm}$, with straight golden-brown hygroscopic hairs. Fig. 6 .

RECOGNITION. Barleria negeleensis is allied to B. quadrispina but differs in (1) the shortly sheathing leaf base and the typically longer and proportionately narrower, linearoblong to narrowly oblong-elliptic mature leaves (leaf base not sheathing in B. quadrispina and blade obovate, oblanceolate or oblong-elliptic); (2) the bracts of the inflorescence being imbricate at least in the lower portion of the spike and these largely or partially enclosing the cymes (vs bracts not imbricate and cymes usually clearly exposed); (3) the bracts having a stout terminal spine $4-8 \mathrm{~mm}$ long (vs bracts with short slender terminal spine); (4) the broader and more gradually narrowed anterior and posterior calyx lobes, $4-6 \mathrm{~mm}$ wide (vs anterior and posterior calyx lobes markedly acuminate and only $1.5-3(-4) \mathrm{mm}$ wide at base), and (5) the larger capsules, $13.5-16 \mathrm{~mm}$ long with beak only c. $1 / 4$ the total length of the capsule and seeds c. $6.5 \mathrm{~mm}$ wide (vs capsule $9-11 \mathrm{~mm}$ long with beak c. $1 / 3$ the total length of the capsule and seeds c. $2.5-$ $4 \mathrm{~mm}$ wide in B. quadrispina). See Table 2.

DISTRIBUTION. This species is restricted to the Bale and Sidamo Floristic Regions of southern Ethiopia. Map 1, black squares.

SPECIMENS STUDIED. ETHIOPIA. Bale Region: c. $52 \mathrm{~km} \mathrm{~N}$ of Sidambale Bridge towards Dolo Menna, $5^{\circ} 55^{\prime} \mathrm{N}, 39^{\circ} 37^{\prime} \mathrm{E}$, 1650 m, 20 Dec. 2002, Friis et al. 11071 (C, K, ETH). Sidamo Region: near Wadera, 1700 m, 6 Jan. 1959, Mooney 7706 (EA, ETH, PRE); Borana Awraja, $42 \mathrm{~km}$ SW of Negele Borana, along the road leading to Wellensu [Wolensu] Ranch, 1440 m, 24 Dec. 1981, Mesfin T. E Tewolde B. G. E. 2636 (ETH); $31 \mathrm{~km}$ from Negele towards Filtu, $5^{\circ} 13^{\prime} \mathrm{N}, 39^{\circ} 47^{\prime} \mathrm{E}, 1640 \mathrm{~m}, 14$ Dec. 1990, Sebsebe D. E Ensermu K. 2658 (ETH holotype, $\mathrm{K}$ isotype).

HABITAT \& ECOLOGY. Barleria negeleensis occurs in open grassland and grassy-scrub with scattered Acacia,
Combretum, Commiphora and/or Terminalia or in more dense Acacia-Commiphora woodland with Barbeya oleoides Schweinf., in sandy soil overlying granite or on limestone. It occurs at $1400-1700$ m elevation.

CONSERVATION STATUS. This species has a very small range mainly in the vicinity of Negele in southern Ethiopia. It has an EOO of $2117 \mathrm{~km}^{2}$ which falls within the "Endangered" range threshold under IUCN criterion B1. It has been recorded as very local but common within an area of $400 \mathrm{~m}^{2}$ at the type locality. In the documentation of the Liben Plains and Negele Woodlands Important Bird Area (BirdLife International 2017c), which includes the type locality for B. negeleensis, the threat pressure is recorded as high. This area is unprotected and is impacted by development of new settlements; there is also a potential threat from plans to develop a new airport for Negele in part of this area. Analysis of Google Earth imagery shows that there has been significant clearance for agriculture and settlement in the vicinity of Negele town and to the east covering an area of up to c. $250 \mathrm{~km}^{2}$ (just over $10 \%$ of the total EOO). However, it should be noted that this species has not so far been collected in these most impacted areas. Further, this species' range has not been well botanised beyond the few main access roads and there is still extensive intact natural habitat within its EOO, although it is not clear as to how much of this is suitable for this species. In view of the limited information available to date, this species is considered to be Data Deficient (DD) but it may prove to be unthreatened as the threats within its range are quite localised.

ETYMOLOGY. Barleria negeleensis is named after the small town of Negele (Negele Borana or Neghelle), close to which three of the four known specimens of this species have been collected.

NOTES. This is a second species within sect. Prionitis allied to Barleria quadrispina. It is easily separated by the characters given in the Recognition section, and this species has a very distinctive general appearance quite unlike that of $B$. quadrispina. The two are compared, together with B. ferox, in Table 2.

The collection from Bale Region, Friis et al. 11071, is considered to be a depauperate specimen of this species, although it is noteworthy that the inflorescence is less densely hairy than in other flowering specimens, with shorter bristly eglandular hairs, and that the leaves dry a darker green tinged purple, whilst the Sidamo material has yellow-green leaves. More ample material from the Bale site is desirable; it may be a distinct regional form.

There are also a number of other potentially distinct taxa within the Barleria quadrispina complex in the Horn of Africa. Of particular note are robust shrubby or sometimes scandent plants from the Bale and Sidamo Floristic Regions of Ethiopia with large, broadly elliptic 


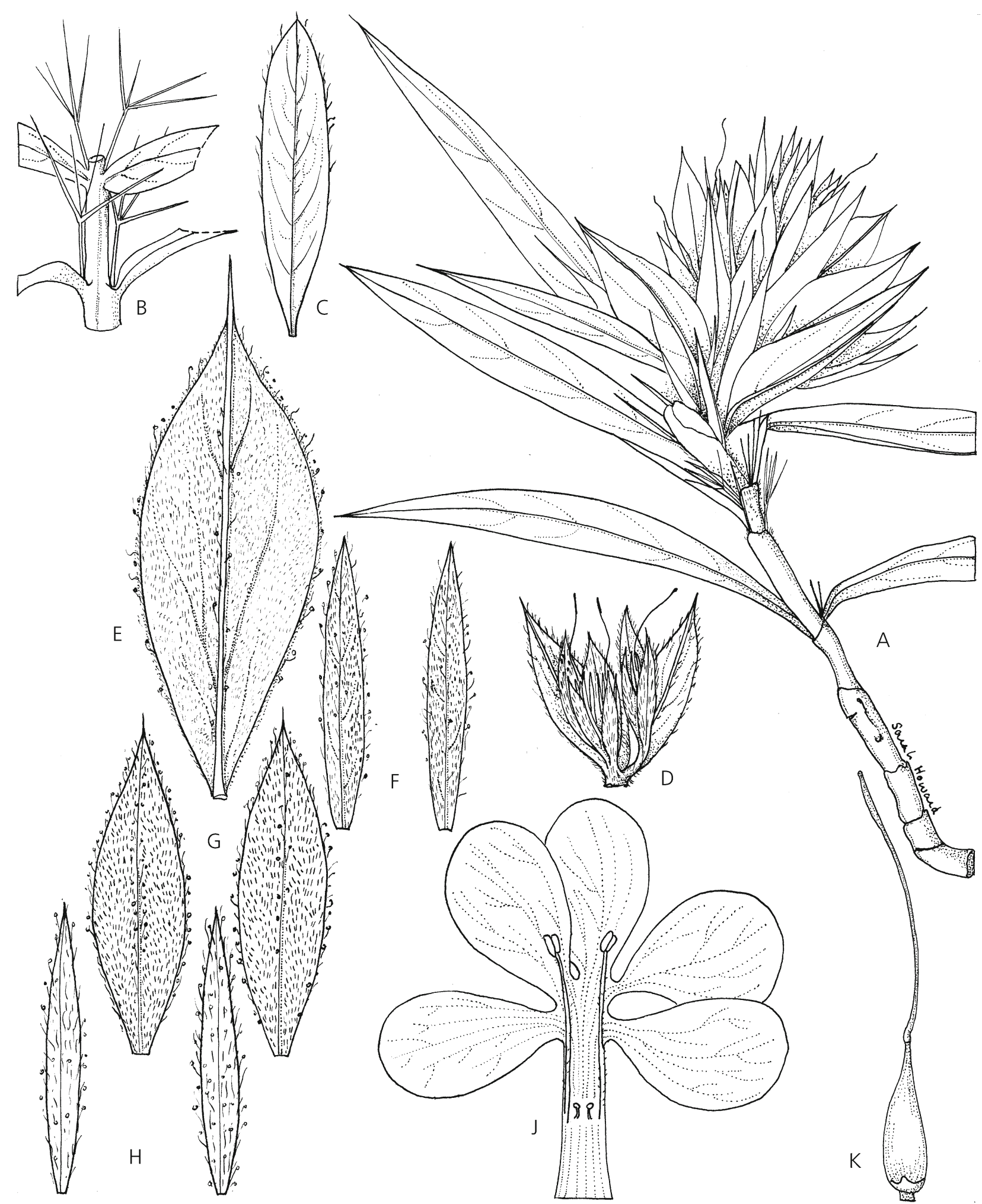

Fig. 6. Barleria negeleensis. A habit, flowering branch with fallen corollas $\times 1$; B axillary spines $\times 1$; $C$ leaf blade from distal portion of stem, abaxial surface $\times 1$; D cyme $\times 1$; E bract, external surface $\times 3$; F pair of bracteoles, external surfaces $\times 3$; G anterior (left) and posterior (right) calyx lobes $\times 3 ; \mathrm{H}$ lateral calyx lobes $\times 3$; J dissected corolla with androecium $\times 2 ; \mathrm{K}$ maturing gynoecium $\times 4$. A \& D from Mooney 7706; B, C \& E - J from Mesfin T. \& Tewolde B. G. E. 2636. DRAWN BY SARAH HOWARD. 
leaves up to $8 \times 5 \mathrm{~cm}$ (Bidgood et al. 4961, Friis et al. 10949, 14746, Gilbert et al. 8257, Gilbert E Sebsebe D. 8628). This taxon was treated as a form of B. quadrispina in the Flora of Ethiopia E Eritrea (Ensermu 2006) but appears to be sufficiently distinct at least for infraspecific separation. Hedrén (2006a) also noted some distinct forms of this species in Somalia that may warrant distinction. A full revision of the Barleria quadrispina complex is required to fully delimit the taxa, but the two species described here are very clearly distinct.

Barleria shebelleensis Ensermu $\mathcal{E}$ I. Darbysh. sp. nov. Type: Somalia, Bulo Burte Distr., $2 \mathrm{~km} \mathrm{~N}$ of Bulo Burte, 9 Dec. 1987, Kuchar 17588 (holotype K sheet 1 — K000963626; isotype K sheet 2 - K000963627).

http://www.ipni.org/urn:lsid:ipni.org:names:77167083-1

Barleria hochstetteri sensu Hedrén (2006a: 435) pro parte, non Nees.

Barleria sp. (= Kuchar 16682) sensu Ensermu (2006: 403).

Woody-based perennial herb or shrublet; stems erect to trailing-decumbent, 5 - $40(?-100) \mathrm{cm}$ high, much branched, 4-angular when mature with 4 narrow \pm conspicuous furrows that have a more dense white indumentum than the rest of the stem, this pubescent with white appressed medifixed and retrorse hairs, often densely so, interspersed with some patent glandular hairs on distal internodes; internodes 3 $6 \mathrm{~cm}$ long. Leaves subsessile, blade bluish-green, oblong-elliptic to oblong-lanceolate, $13-62 \times 5-14$ $\mathrm{mm}$, base obtuse or rounded, margin entire, apex acute to rounded and mucronate, surfaces with appressed long medifixed hairs on both surfaces, distal leaves with spreading glandular hairs beneath towards the margins, young leaves can also be finely puberulent; lateral veins very faint, $3-4$ pairs. Inflorescences axillary, cymes bearing 1 - 3 flowers; peduncle $1-4.5 \mathrm{~mm}$ long, hairs as stems; bracteoles foliaceous, oblong-elliptic or those of lateral flowers more oblanceolate, $822 \times 2-9 \mathrm{~mm}$, often oblique towards the mucronate apex, pubescent with medifixed hairs and patent glandular hairs, larger pairs tripliveined; pedicels $1.5-4.5 \mathrm{~mm}$ long. Calyx with lobes very unequal, anterior lobe linear-lanceolate, $4.5-8.7 \times 1-1.5 \mathrm{~mm}$, widest at base, apex entire or sometimes bifid; posterior lobe much larger, oblong-oblanceolate, $9-15.5 \times 1.5-3.3 \mathrm{~mm}$, widest in distal third, apex acute or attenuate; both lobes with short spreading glandular hairs and long appressed anvil-shaped biramous hairs, or these simple along lobe margins, surfaces can also be white eglandularpuberulous; lateral lobes linear-lanceolate, $4-6 \times 0.7$ - $1 \mathrm{~mm}$. Corolla white, with (or ?without) pink streaks in the throat, $18-27 \mathrm{~mm}$ long, eglandular-puberulous externally on distal portion of tube and on limb with or without few interspersed glandular hairs; tube 11.5 - $15.5 \mathrm{~mm}$ long, proximal portion $\pm 1.5-2 \mathrm{~mm}$ wide, throat gradually funnel-shaped, to $3.7-5.5 \mathrm{~mm}$ wide at mouth; limb in " $4+1$ " configuration; abaxial lobe offset by $1.8-3.3 \mathrm{~mm}$, broadly obovate, $5.5-10.5 \times 4.7$ - $8.8 \mathrm{~mm}$, apex rounded or truncate; lateral lobes obovate-orbicular, $4-8.5 \times 3.5-7.5 \mathrm{~mm}$, apices rounded, adaxial lobes obovate or obovate-elliptic, 3.5 - $7.5 \times 2.8-5.5 \mathrm{~mm}$. Stamens inserted $3-5.5 \mathrm{~mm}$ above base of corolla tube, filaments $8-16 \mathrm{~mm}$ long, glabrous; anthers 1.8 - $2.8 \mathrm{~mm}$ long; staminodes 3, lateral staminodes $0.3-1 \mathrm{~mm}$ long, antherodes lacking. Ovary $\pm 2.5 \mathrm{~mm}$ long, puberulous with ascending hairs; style 14 - $16 \mathrm{~mm}$ long, glabrous or pubescent at base; stigma linear, $1-1.2 \mathrm{~mm}$ long. Capsule 8.5 - $11.5 \times 3.5-4 \mathrm{~mm}$, eglandularpuberulous; seeds $3-4 \times 2.6-3.8 \mathrm{~mm}$, ovate in face view, covered with curled cream-coloured hygroscopic hairs. Fig. 7.

RECOGNITION. Barleria shebelleensis falls within the $B$. argentea Balf. f. $-B$. parviflora T. Anderson complex but is easily separated from all other species in that group by having markedly dimorphic outer calyx lobes, the anterior lobe being linear-lanceolate and only marginally larger and wider than the lateral lobes whilst the posterior lobe is considerably larger (often twice as long) and oblong-oblanceolate in shape. The markedly 4-angular stems with \pm conspicuous furrows at each angle also separate this species from its closest allies. B. shebelleensis is morphologically most similar to B. parviflora T. Anderson from which it differs in having 1 - 3-flowered cymes (flowers always solitary in B. parviflora) with a \pm well-developed pedicel $1.5-$ $4.5 \mathrm{~mm}$ long and bracteoles that are foliaceous and \pm markedly larger than the calyx lobes and dissimilar in shape (in B. parviflora the flowers are sessile, immediately subtended by the bracteoles which are held erect, partially enveloping the calyx and \pm closely resembling the outer calyx lobes in shape and size), and a puberulous ovary and capsule (glabrous in $B$. parviflora). Further, the peduncle of $B$. parviflora is often much longer than in B. shebelleensis, typically $5-$ 20 (- 25) $\mathrm{mm}$ long, and the outer calyx lobes of B. parviflora are not dimorphic, both being ovate to oblong-lanceolate.

Barleria shebelleensis has previously been included within $B$. hochstetteri Nees with which it is vegetatively similar but it is easily separated from that species by the very different calyx, the outer lobes both being ovate to oblong-lanceolate in B. hochstetteri; the more contracted inflorescences, $B$. hochstetteri having peduncles $8-25(-38) \mathrm{mm}$ long and pedicels $5-15(-27)$ mm long; and the less markedly zygomorphic corolla with the abaxial lobe only being offset by up to $3.3 \mathrm{~mm}$ (vs $4.5-7 \mathrm{~mm}$ in $B$. hochstetteri). 


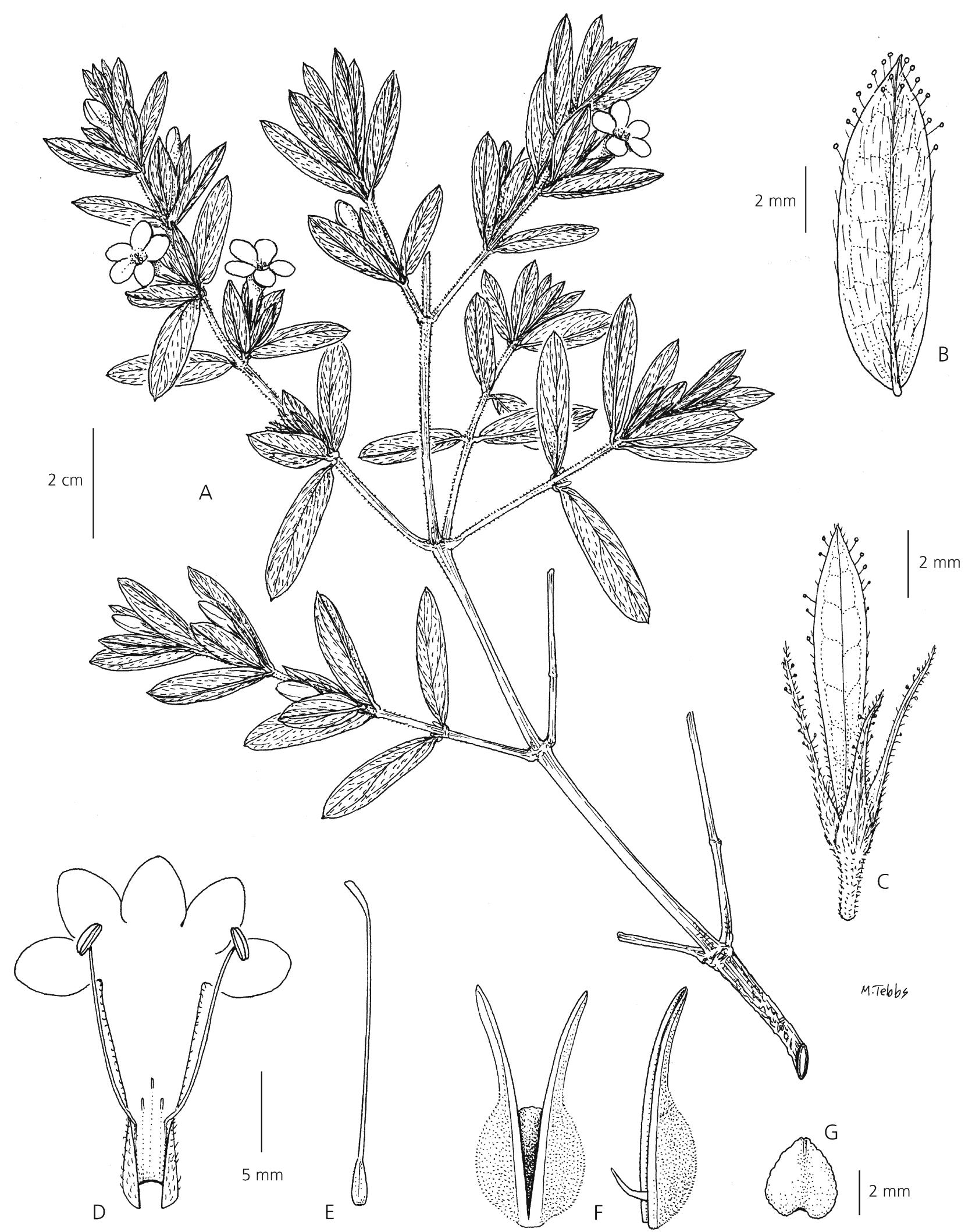

Fig. 7. Barleria shebelleensis. A habit, flowering branch; B bracteole, external surface; C calyx; D dissected corolla with androecium; E gynoecium; F capsule with seeds, and single capsule valve; G seed. A - C \& E - G from Kuchar 17588; D from Kuchar 17046. DRAWN BY MARGARET TEBBS. 
DISTRIBUTION. Barleria shebelleensis is restricted to central and southern Somalia (Flora of Somalia regions C2, S2 and S3), along the lower catchment of the Shebelle River. It may also occur along the southeastern Ethiopian portion of that river which forms the border between Harar and Bale Floristic regions. Map 1, red circles.

COLLECTIONS STUDIED. SOMALIA. Janaale area, flood plain of the Shabeelle R., between $1^{\circ} 30^{\prime}$ and $2^{\circ} 00^{\prime} \mathrm{N}$, fl. \& fr. 2 - 3 Jan. 1978, Virgo 40 (K); Hiiraan Region, Bulo Burte Distr., 11 km NNW of Bulo Burte, fl. \& fr. 4 Dec. 1984, Kuchar 16682 (K); Bulo Burte Distr., 25 km W from Bulo Burte on road to Mukayle, $3^{\circ} 48^{\prime} \mathrm{N}$ $45^{\circ} 21$ 'E, fl. \& fr. 1 July 1986, Kuchar 17046 (K); Shabeellaha Hoose Region, c. $45 \mathrm{~km}$ SW of Afgooye [Afgoi] along the main road to Shalaanbood [Shalambod], $1^{\circ} 48^{\prime} \mathrm{N} 44^{\circ} 44^{\prime} \mathrm{E}$, fl. 29 May 1987, Alstrup $\mathcal{E}^{2}$ Michelsen 66 (K); Jubbada Dhexe Region, 41 km NE of Jilib [Gelib], along the main road to Baraawe [Brava], $0^{\circ} 28^{\prime} \mathrm{N} 43^{\circ} 12^{\prime} \mathrm{E}$, fl. 13 June 1987, Friis, Vollesen $\mathcal{E}^{\circ}$ Abdisalam Sheikh Hassan 5012 (K); Jalalaksi Distr., $8 \mathrm{~km}$ SE of Buur Weyn, $3^{\circ} 33^{\prime} \mathrm{N} 45^{\circ} 36^{\prime} \mathrm{E}$, fl. \& fr. 11 Aug. 1987, Kuchar 17321 (K); Jalalaksi/Bulo Burte Distr. boundary, $7.5 \mathrm{~km}$ EEN of Buur Weyn, $3^{\circ} 37^{\prime} \mathrm{N}$ 453'ㄹ, fl. \& fr. 11 Aug. 1987, Kuchar 17325 (K); Bulo Burte Distr., $2 \mathrm{~km} \mathrm{~N}$ of Bulo Burte, $3^{\circ} 52^{\prime} \mathrm{N} 45^{\circ} 35^{\prime} \mathrm{E}$, fl. 9 Dec. 1987, Kuchar 17588 (K, holotype and isotype). HABITAT \& ECOLOGY. This species is recorded from the ground layer of open woodland and scrub usually on alluvial clay or silt plains, with variously Acacia nilotica (L.) Delile, Acacia oerfota (Forssk.) Schweinf., Acacia zanzibarica (S. Moore) Taub., Balanites aegyptiaca (L.) Delile, Blepharispermum fruticosum Klatt, Cordia sinensis Lam. and/or Dalbergia commiphoroides Baker $\mathrm{f}$. in the shrub or tree layer. It grows at $25-200 \mathrm{~m}$ elevation.

CONSERVATION STATUS. This species is currently known only from central and southern Somalia along the Shebelle River catchment, with an EOO of $18,634 \mathrm{~km}^{2}$ which falls within the "Vulnerable" range threshold under IUCN criterion B1. It has been recorded as locally common by several collectors. Some of the collecting sites had been impacted by shifting cultivation or by removal of larger woody species for fuelwood at the time of collection but this does not appear to have negatively impacted this species. That said, study of Google Earth imagery indicates that there has also been significant conversion of natural vegetation to more intensive agricultural land in some parts of its range along the Shebelle, particularly in the Janalle area west-southwest of Mogadishu. This will very likely have led to some population declines in that area. There is also considerable pressure on the water resources of the Shebelle both in Ethiopia and Somalia, with future water demands projected to increase markedly (Michalscheck et al. 2016). These long-term changes to water levels may impact the vegetation of the surrounding catchment. The Shebelle-Juba Catchments Freshwater Ecoregion has been assessed as Vulnerable by Thieme et al. (2005), citing gowing agricultural pressure and human population growth as the most likely threats, although they acknowledge that limited information is available on its curent status. With less than 10 locations known and with inferred decline in extent and quality of habitat, this species is therefore provisionally assessed as Vulnerable VU Blab(iii), although with more information desirable on its current range and abundance.

ETYMOLOGY. Barleria shebelleensis is named after the Shebelle River, as this species is closely associated with the catchment of this major river.

NOTES. The combination of a prominently beaked, 2seeded capsule, seeds with wavy hygroscopic hairs, an androecium comprising two fertile stamens and three minute staminodes and the plants lacking spines place Barleria shebelleensis in sect. Somalia (Oliv.) Lindau (Balkwill \& Balkwill 1997; Darbyshire 2009). This species also has medifixed hairs on the vegetative parts, bluish-green foliage and corollas which are (at least sometimes) streaked in the throat, characters that together place this species in Balkwill's (1993) "Group 1 " of sect. Somalia which contains the Barleria argenteaparviflora complex. This group is challenging taxonomically, containing a number of closely allied species in NE Africa and Arabia that are usually separable by a range of morphological characters but with occasional intermediates suggesting that hybridisation is not uncommon (see discussion in Darbyshire 2010: 407). This complex is in need of detailed taxonomic study, combining molecular and morphological analyses. That said, B. shebelleensis is one of the most easily recognisable and discrete members of this complex in view of its unique calyx configuration in which the anterior lobe is more similar to the lateral lobes than it is to the markedly enlarged posterior lobe. It also has a less markedly zygomorphic corolla than other members of this complex, as the abaxial lobe is only shortly offset.

M. Hedrén had annotated the folders of this species at $\mathrm{K}$ with the provisional name "kuchar" but in the Flora of Somalia account (Hedrén 2006a) he treated it as a form of Barleria hochstetteri noting it as "a fairly distinct form...similar to B. argentea in its narrow calyx lobes, but has an upright shrubby growth and agrees with $B$. hochstetteri in the large and wide leaves and more evenly dispersed hairs, as well as spreading thin hairs" (p. 436). Hedrén did not include Virgo 40 and Alstrup $\mathcal{E}^{2}$ Michelsen 66 within this form, listing these separately as specimens of $B$. hochstetteri tending towards $B$. argentea. However, these two specimens clearly belong to the same taxon as the rest of the material cited above. He appears to have missed the fact that the anterior and posterior calyx lobes are markedly dimorphic in this species.

On Kuchar 17046, this species is recorded as a "dwarf shrub to $1 \mathrm{~m}$ " but on the three sheets of that collection at 
$\mathrm{K}$, the specimens are less than $40 \mathrm{~cm}$ tall in keeping with all other material seen, hence the maximum height is recorded as "? $-100 \mathrm{~cm}$ " in the description.

\section{The status of Barleria parviflora in Somalia}

Hedrén (2006a) considered that Barleria argentea and B. parviflora may be conspecific. He did not record B. parviflora from Somalia but noted some collections from northen Somalia "approach B. parviflora by having bracts that are lanceolate to ovate (rather than triangular)" (p. 435). However, whilst there are some potential intermediate specimens, these two species are usually very easily separated (e.g. by the glabrous capsules of B. parviflora; see Ensermu 2006 for other differences) and should be maintained as distinct species. B. parviflora sensu stricto occurs in northern Somalia where it is represented by a number of specimens; these are cited below, together with representative specimens from the other countries in which it occurs (two per country).

Barleria parviflora $R$. Br. ex T. Anderson (1863: 29); Clarke (1899: 156); Wood (1997: 272); Ensermu (2006: 423); Darbyshire et al. (2015: 345).

DISTRIBUTION. Barleria parviflora is recorded from Saudi Arabia, Yemen, Sudan, Eritrea (fide Ensermu 2006), Ethiopia and Somalia.

COLLECTIONS STUDIED. SOMALIA. Golis Range, Somaliland, fl. 15 May 1906, Drake-Brockman 247 (K); Hargeisa, fl. \& fr. July 1929, Burne 82 (K); Hargeisa, $9^{\circ} 33^{\prime} \mathrm{N}, 44^{\circ} 1$ 'E, fl. \& fr. 23 Sept. 1932, Gillett 3991 (K); Duwi Pass, $10^{\circ} 5^{\prime} \mathrm{N}$, $44^{\circ} 15^{\prime} \mathrm{E}$, fl. \& fr. 19 Oct. 1932, Gillett 4365 (K); $9^{\circ} 48^{\prime} \mathrm{N}$, $43^{\circ} 17^{\prime} \mathrm{E}$, old infl. May 1933, Godding 32 (K); Buramo, $9^{\circ} 56^{\prime} \mathrm{N}, 43^{\circ} 11^{\prime} \mathrm{E}$, fl. \& fr. June 1933, Godding 56 (K); "British Somaliland", without precise locality, fl. 3 Sept. 1941, Peck 423 (EA, K); Wadaba, Gubari, fl. \& fr. 6 June 1945, Glover $\mathcal{E}$ Gilliland 1200 (EA, K); Elmis (Summit), fl. 5 May 1949, Guichard in EA 10679 (EA); 8 miles NW of Borama, fl. \& fr. 4 Oct. 1954, Bally 9955 (EA, K); 18 miles E of Hargeisa, fl. \& fr. 25 Sept. 1956, Bally 10830 (K); Hargeisa, fl. 6 Oct. 1962, Keogh 42 (K); 10 km NW of Hargeisa, $9^{\circ} 35^{\prime} \mathrm{N} 44^{\circ} 00 ' \mathrm{E}$, fl. \& fr. 6 Nov. 1969, Robertson 1343 (EA, ETH); Sheikh, fl. \& fr. May 1972, Wood 5/72/38 (EA, K); Togdheer Region, Sheek Distr., Gaan Libah, 9 $52^{\prime} \mathrm{N}, 4^{\circ} 50^{\prime} \mathrm{E}$, fl. \& fr. 19 Nov. 1979, Hansen et al. 6453 (EA, K); NW Somalia site A/18, $10^{\circ} 12^{\prime} \mathrm{N}, 43^{\circ} 36^{\prime} \mathrm{E}$, fl. \& fr. 2 July 1981, Gillett $\mathcal{E}$ Watson 23701 (EA, K); without locality \& date, fl., Godding 47 (K). REPRESENTATIVE SPECIMENS FROM OTHER COUNTRIES. SAUDI ARABIA. $45 \mathrm{~km}$ S of Dharan, Najran road, fl. \& fr. 29 April 1979, Collenette 1476 (K); 1/4 way up the escarpment, Taif - Jeddah road, fl. 12 March 1982, Collenette 3381 (K). YEMEN. E side of the Haraz below Maghraba, fl. \& fr. 2 June 1977, Wood 1683 (K); between Bab Bahel and Mausana in the Haraz, fl. \& fr. 24 Nov. 1977, Wood 2135 (K). SUDAN. Erkowit, fl. 10 Sept. 1868, Schweinfurth 255 (K) \& fl. 16 May 1907, Broun 1186 (K!). ETHIOPIA. Afar Region, Erer R. area, $60 \mathrm{~km} \mathrm{~W}$ of Dire Dawa on hwy. to Addis Ababa, 9 31 'N 41 ${ }^{\circ}$ 25'E, fl. \& fr. 23 Aug. 1961, Burger 632 (K); Tigray Region, $17 \mathrm{~km}$ W of Mekelle, on the eastern slope of the Giba R. valley, $13^{\circ} 31^{\prime} \mathrm{N} 39^{\circ} 22$ 'E, fl. \& fr. 12 Oct. 1995, Friis et al. 6707 (K).

CONSERVATION STATUS. Barleria parviflora is a widespread and locally common species of the dry bushlands and woodlands of Somalia-Masai phytogeographic region, particularly in Ethiopia, and is considered to be of Least Concern (LC).

\section{Acknowledgements}

I. Darbyshire would particularly like to thank Dr Tigist Wondimu, Chair of the Department of Plant Biology and Biodiversity Management at Addis Ababa University, and Professor Sebsebe Demissew of the same department for kindly inviting me to speak at the memorial lecture for the late Professor Ensermu Kelbessa, held on $20^{\text {th }}$ February 2017. Prof. Sebsebe and a second, anonymous reviewer are also thanked for their helpful comments on an earlier draft of this manuscript. We thank the curators at the EA and PRE herbaria for providing access to their Barleria collections, and all the many field botanists who collected / assisted in the collection of these new species. We thank Andrew Brown, Linda Gurr, Sarah Howard and Margaret Tebbs for drawing the illustrations of the new species and Erin Tripp of University of Colorado for providing the photograph of Barleria baluganii.

Open Access This article is distributed under the terms of the Creative Commons Attribution 4.0 International License (http://creativecommons.org/ licenses/by/4.0/), which permits unrestricted use, distribution, and reproduction in any medium, provided you give appropriate credit to the original author(s) and the source, provide a link to the Creative Commons license, and indicate if changes were made.

\section{References}

Anderson, T. (1863). An enumeration of the species of Acanthaceae from the continent of Africa and the adjacent islands. J. Proc. Linn. Soc., Bot. 7: $13-$ 54.

Balkwill, M. J. (1993). A reappraisal of the generic limits and subdivision of Barleria L. (Acanthaceae). Unpubl. Ph.D. thesis, University of Witwatersrand, Johannesburg.

\& Balkwill, K. (1997). Delimitation and infrageneric classification of Barleria (Acanthaceae). Kew Bull. 52: 535 - 573. 
\& - (1998). A preliminary analysis of distribution patterns in a large, pantropical genus, Barleria L. (Acanthaceae). J. Biogeogr. 25: 95 - 110.

BirdLife International (2017a). Important Bird Areas factsheet: Bonga forest. [http://www.birdlife.org. Accessed: June 2017].

(2017b). Important Bird Areas factsheet: Metu Gore - Tepi forests. [http://www.birdlife.org. Accessed: June 2017].

(2017c). Important Bird Areas factsheet: Liben plains and Negele woodlands. [http://www.birdlife.org. Accessed: June 2017].

Clarke, C. B. (1899). Barleria. In: W. T. Thiselton-Dyer (ed.), Flora of Tropical Africa, vol. 5: 140 - 169. L. Reeve \& Co., London.

Darbyshire, I. (2009). A reassessment of the status of Barleria sect. Cavirostrata (Acanthaceae) in tropical Africa, with a new species, B. richardsiae, described from the TanzaniaZambia border region. Kew Bull. 63: 601 - 611 .

- (2010). Barleria. In: H. J. Beentje (ed.), Flora of Tropical East Africa. Acanthaceae (Part 2), pp. 325 442. Royal Botanic Gardens, Kew.

(2015). Barleria. In: J. R. Timberlake \& E. S. Martins (eds), Flora Zambesiaca 8 (6): 37 - 122. Royal Botanic Gardens, Kew.

—_, Kordofani, M., Farag, I., Candiga, R. \& Pickering, H. (2015). The Plants of Sudan and South Sudan. An annotated checklist. Royal Botanic Gardens, Kew.

— \& Luke, Q. (2016). Barleria mirabilis (Acanthaceae): a remarkable new tree species from west Tanzania. Kew Bull. 17: 13 (6 pages).

—_, Vollesen, K. \& Ensermu Kelbessa (2010). Acanthaceae (Part 2). In: H. Beentje (ed.), Flora of Tropical East Africa. Royal Botanic Gardens, Kew.

Ensermu Kelbessa (1982). A palynological-taxonomic study of the genus Asystasia and a palynological study of some related genera in the Acanthaceae. M.Sc. thesis, Addis Ababa University.

(1989a). Two new species of Justicia sect. Ansellia (Acanthaceae) from E and NE tropical Africa. Nordic J. Bot. 9: 399 - 404.

(1989b). A new species of Asystasia (Acanthaceae) from Ethiopia. Bull. Jard. Bot. Natl. Belg. 59: 413 - 418.

- (1990). Justicia sect. Ansellia (Acanthaceae). Symb. Bot. Upsal. 29(2): 1 - 96.

(1993). Studies in the genus Asystasia (Acanthaceae) in Africa I: two new species from tropical Africa. Opera Bot. 121: 153 - 158 .

(1994). A revision of Asystasia gangetica (L.) T. Anders. (Acanthaceae). In: J. H. Seyani \& A. C. Chikuni (eds), Proceedings of the $13^{\text {th }}$ Plenary Meeting of AETFAT, Zomba, Malawi, 2-11 April 1991. Vol. 1. Plants for People, pp. 333 - 346. National Herbarium and Botanic Garden of Malawi, Zomba.

(1998). Studies in the genus Asystasia (Acanthaceae) in Africa II: further new species. Kew Bull. 53: 929 - 935.
(2006). Acanthaceae. In: I. Hedberg et al. (eds), Flora of Ethiopia E Eritrea, vol. 5: 345 - 495. The National Herbarium, Addis Ababa University \& The Department of Systematic Botany, Uppsala University.

- (2009). Three new species of Acanthaceae from Ethiopia. Kew Bull. 64: 57 - 65.

—, Brummitt, R. K. \& Furness, C. A. (1992). A reconsideration of Asystasiella Lindau (Acanthaceae). Kew. Bull. 47: 669 - 675.

Hedberg, I., Ensermu Kelbessa, Edwards, S., Sebsebe Demissew \& Persson, E. (eds) (2006). Flora of Ethiopia E Eritrea, vol. 5. The National Herbarium, Addis Ababa University \& The Department of Systematic Botany, Uppsala University.

Hedrén, M. (2006a). Barleria. In: M. Thulin (ed.), Flora of Somalia, vol. 3: 427 - 442. Royal Botanic Gardens, Kew.

___ (2006b). New species and combinations in Acanthaceae from Somalia. Willdenowia. 36: 751 - 759.

IUCN (2012). IUCN Red List Categories and Criteria. Version 3.1. Second Edition. IUCN Species Survival Commission, Gland \& Cambridge.

IUCN Standards and Petitions Subcommittee (2017). Guidelines for Using the IUCN Red List Categories and Criteria. Version 13. Prepared by the Standards and Petitions Subcommittee. [http://www.iucnredlist.org/ documents/RedListGuidelines.pdf. Accessed: June 2017].

Michalscheck, M., Petersen, G. \& Gadein, H. (2016). Impacts of rising water demands in the Juba and Shabelle river basins on water availability in south Somalia. Hydrological Sci. J. 61: 1877 - 1889.

Sebsebe Demissew, Bytebier, B., et al. (2016). Professor Ensermu Kelbessa. J. East African Nat. Hist. 105: 203 -211 .

Thieme, M. L., Abell, R., Stiassny, M. L. J., Skelton, P., Lehner, B., Teugels, G. G., Dinerstein, E., Toham, A. K., Burgess, N. \& Olson, D. (2005). Freshwater Ecoregions of Africa and Madagascar. A conservation assessment. World Wildlife Fund; Island Press, Washington.

Vivero, J. L., Ensermu Kelbessa \& Sebsebe Demissew (2005). The Red List of Endemic Trees and Shrubs of Ethiopia and Eritrea. Fauna \& Flora International, Cambridge. $\&-$ (2006). Progress on the Red List of plants of Ethiopia and Eritrea: conservation and biogeography of endemic flowering taxa. In: S. A. Ghazanfar \& H. J. Beentje (eds), Taxonomy and Ecology of African Plant, their Conservatino and Sustainable Use. Proceedings of the 17th AETFAT Congress, Addis Ababa, Ethiopia, pp. 761 - 778. Royal Botanic Gardens, Kew \& National Herbarium, Addis Ababa University.

Vollesen, K. \& Ensermu Kelbessa (2010). Asystasia. In: H. J. Beentje (ed.), Flora of Tropical East Africa. Acanthaceae (Part 2), pp. 325 - 442. Royal Botanic Gardens, Kew.

Wood, J. R. I. (1997). A Handbook of the Yemen Flora. Royal Botanic Gardens, Kew. 